\title{
25. MAGNETIC PROPERTIES OF LEG 158 CORES: THE ORIGIN OF REMANENCE AND ITS RELATION TO ALTERATION AND MINERALIZATION OF THE ACTIVE TAG MOUND ${ }^{1}$
}

\author{
Xixi Zhao, ${ }^{2,3}$ Bernie Housen, ${ }^{4}$ Peter Solheid, ${ }^{4}$ and Weixin $\mathrm{Xu}^{5}$
}

\begin{abstract}
We present detailed rock magnetic results of sulfide and basalt samples recovered at the Trans-Atlantic Geotraverse (TAG) hydrothermal mound on the Mid-Atlantic Ridge near $26^{\circ} \mathrm{N}$. The study involves a series of rock magnetic measurements and characterization of 46 minicore samples. These measurements were designed to investigate the origin of the magnetic remanence of the samples and allow an unambiguous identification of magnetic minerals and their distribution in the TAG mound. The Leg 158 cores displayed a multicomponent magnetization nature. No reversed magnetization was observed, which was expected as the mound was formed within the last $140 \mathrm{ka}$. Variations in magnetic properties correlate to changes in lithology that result from differences in the abundance and size of magnetic particles. Almost all sulfide samples from the TAG drilling areas contain small amounts of pyrrhotite and magnetite as shown by the transition around $40 \mathrm{~K}$ and by the Verwey transition in the vicinity of $118 \mathrm{~K}$ during the low-temperature cycling. The magnetization shows complexity both on a local scale and on a larger scale, with highly variable inclinations over relatively short distances along the core sections. The available evidence suggests that the remanence of sulfide samples is partly or wholly chemical in origin, probably as a result of heating and alteration related to hydrothermal fluid circulation. The combined investigation suggests that the magnetic properties of the basalt samples from the TAG-4 area are controlled mainly by magnetite and minor amounts of maghemite and hematite. The magnetic minerals of the basalts are of variable particle size, but fall within the pseudo-single domain size range $(0.2-14 \mu \mathrm{m})$. The mean inclination of $20.8^{\circ}$ obtained from the basalt samples is a significant departure from the expected $55^{\circ}$ value and is surprising. One possible paleomagnetic interpretation of the shallow inclination results would be to propose that some tectonic rotation of the TAG mound has occurred since the basaltic lava flows were erupted.
\end{abstract}

\section{INTRODUCTION}

In recent years, it has been recognized that seafloor hydrothermal systems on slow-spreading, sediment-free mid-ocean ridges not only give rise to the formation of hydrothermal sulfide deposits, but also dominate global hydrothermal activity (e.g., Stein and Stein, 1994). Hence seafloor hydrothermal activity is an important contributor to global mass and energy fluxes. Hydrothermal fluid circulation progressively changes the physical and chemical conditions of rocks within the oceanic basement (e.g., Humphris and Thompson, 1978), and provides unique habitats that support chemosynthetic biological communities that are especially adapted to the physico-chemical environment and ephemeral nature of vents (Van Dover et al., 1988; Wirsen et al., 1993).

Leg 158 was particularly designed to investigate the subsurface nature of such a hydrothermal field: the Trans-Atlantic Geotraverse (TAG) mound on the slow-spreading (half rate $1.2 \mathrm{~cm} / \mathrm{yr}$ ) Mid-Atlantic Ridge near $26^{\circ} \mathrm{N}$ (Fig. 1). The principal objectives of drilling Leg 158 were: (1) to study the spatial and temporal variation in the mineralogy, chemistry, and physical properties of the hydrothermal deposits and subsequent zone-refining processes; (2) to investigate the nature of fluid circulations and their effects on mineralogical variations and hydrogeological properties of near- and sub-surface deposits; and (3) to acquire data that can be used to understand the rockseawater interactions and subsequent effects upon the basement rocks (stockwork zone). Seventeen holes were drilled at five loca-

'Herzig, P.M., Humphris, S.E., Miller, D.J., and Zierenberg, R.A. (Eds.), 1998. Proc. ODP, Sci. Results, 158: College Station, TX (Ocean Drilling Program).

${ }^{2}$ Institute of Tectonics, University of California, Santa Cruz, CA 95064, U.S.A. xzhao@earthsci.ucsc.edu

${ }^{3}$ Institute of Geophysics, The Chinese Academy of Sciences, Beijing, China

${ }^{4}$ Institute for Rock Magnetism, University of Minnesota, Minneapolis, MN 55455, U.S.A. (Housen present address: Geology Department, Western Washington University, Bellingham, WA 98225, U.S.A.)

${ }^{5}$ Department of Geology, Arizona State University, Tempe, AZ 85287, U.S.A. tions on the TAG mound (TAG-1 to TAG-5 area in Fig. 1). Although recovery was generally poor (with an average of $\sim 12 \%$ ), we obtained, for the first time, invaluable samples from the subsurface part of a volcanic-hosted submarine hydrothermal system. These samples represent a variety of rock types, including massive granular pyrite, pyrite-anhydrite breccia, pyrite-silica-anhydrite breccia, and slightly altered basalts (see below for stratigraphic details). Because of extremely difficult drilling conditions that included hole instability and cleaning problems, however, originally planned programs for full logging and emplacement of a Circulation Obviation Retrofit Kit (CORK) could not be run. Therefore, some of the particular drilling objectives are entirely dependent on continued studies of this unique set of samples.

Measurement of rock magnetic parameters has been demonstrated to be useful for studying various rock-forming and rock-altering geological processes. Rock magnetic properties can be used to identify the magnetic mineralogy and particle sizes, to subdivide or to correlate different sequences of the deposits, and to help assess the origin and stability of remanent magnetization. Therefore, magnetic properties can be used to understand the relationship of magnetic properties to the alteration regime in the TAG mound.

The purpose of this paper is to present the results of such work carried out on cores recovered from Leg 158 sites from the TAG mound. We will first describe and discuss the paleomagnetic and rock magnetic results of the cores recovered from the TAG-1, TAG2, TAG-4, and TAG-5 areas, focusing on the cores that provided the most readily interpretable data. We then interpret the data in conjunction with lithostratigraphy and other studies. Finally, we use the results to explore the relationship between the magnetic properties and alteration and mineralization of the TAG mound.

\section{SITE AND GEOLOGIC SETTING}

The site locations (Fig. 1) and the structure and morphology of the TAG mound are documented in detail in site chapters of the Leg 158

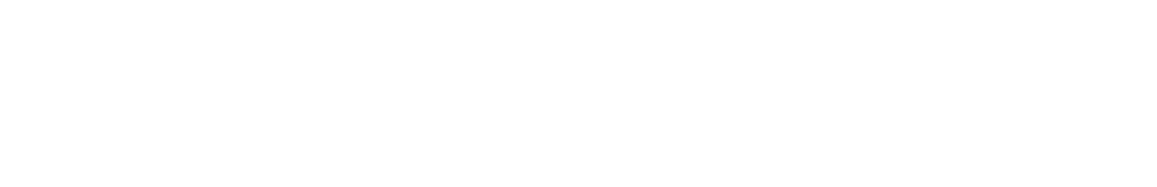




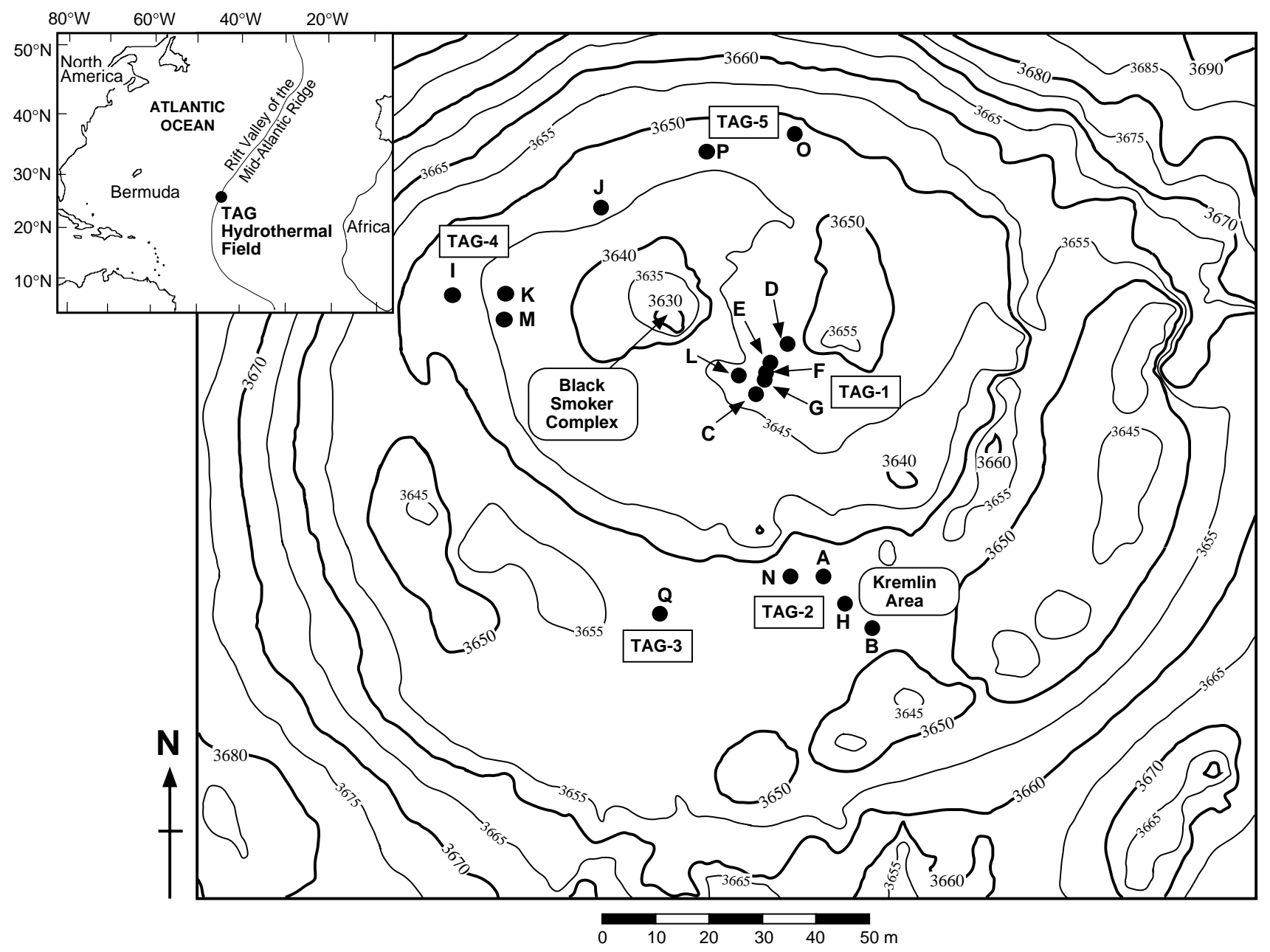

Figure 1. High-resolution bathymetric map (5-m contour interval) of the TAG active mound showing its overall morphology and the major areas of venting (Black Smoker Complex and Kremlin Area). The locations of the holes on the TAG active mound drilled during Leg 158 are also shown. Inset shows the location of the TAG hydrothermal field on the Mid-Atlantic Ridge (after Humphris et al., 1995).

Initial Reports volume and other appropriate papers (see Humphris et al., 1995; Humphris, Herzig, Miller, et al., 1996; Rona and Thompson, 1993) and will be only briefly summarized here.

The TAG mound is the largest hydrothermal field of four along the Mid-Atlantic Ridge (Rona and Thompson, 1993). The TAG site is characterized by active discharge of both high- $\left(\sim 350^{\circ}-400^{\circ} \mathrm{C}\right)$ and low-temperature $\left(200^{\circ}-300^{\circ} \mathrm{C}\right)$ fluids (Tivey et al., 1995), large polymetallic sulfide deposition (Rona et al., 1986; Campbell et al., 1988; Thompson et al., 1988), and an unusual productive and diverse, vent-related, chemosynthetic-based benthic community (Van Dover et al., 1988). Submersible observations confirm that the TAG mound is a large circular feature (about $200 \mathrm{~m}$ in diameter) with two distinctly flat terraces, which may represent two phases of active growth (Humphris et al., 1994). Geochronological studies of samples recovered by dredging suggest that the currently active TAG mound first formed about $140 \mathrm{ka}$ (Lalou et al., 1995). More detailed studies of Alvin samples suggest that activity has been intermittent over the past 20 k.y., with high-temperature activity on average every 5-6 k.y. (Lalou et al., 1995). Present activity commenced only $60 \mathrm{yr}$ ago, after a hiatus of about 4 k.y. (Lalou et al., 1995). Magnetic field data from regional surface-ship studies indicate that a broad north-northeast- to south-southwest-trending area of low residual magnetic intensity about $12 \mathrm{~km}$ long and $8 \mathrm{~km}$ wide is associated with the TAG hydrothermal field (Wooldridge et al., 1992). This has been interpreted to result from hydrothermal alteration of the basaltic crust (Wooldridge et al., 1992). An Alvin survey conducted in 1990 over the TAG mound also revealed a magnetization low located directly beneath the mound with a possible dip to the south (Tivey et al., 1993). Previous work by Hannington et al. $(1988,1992)$ on surface samples collected during Alvin submersible dives to the TAG hydrothermal field indicate significant local enrichment of precious metals such as gold and associated trace metals. Such a finding may well challenge the reigning paradigm that defines a whole class of gold formation models (i.e., gold is no longer just formed on land).

Drilling at the TAG mound was concentrated on a single feature about $200 \mathrm{~m}$ in diameter. Consequently, all drilling locations were considered as one site (Site 957), although holes were grouped in specific areas (Fig. 1). One of the most striking features of the cores recovered from these areas is the dominance of breccias of various types (Fig. 2). Based on the overall internal structure of the mound and the upflow zone, four major zones of the breccias can be distinguished. Zone 1 consists of massive pyrite breccias that dominate the upper 10-20 m at every location (see Humphris et al., 1995). Zone 2 is characterized by anhydrite-rich breccia, which is one of the most remarkable features of the lithology of the mound. The anhydrite-rich zone was not identified at either the TAG-2 or the TAG-4 areas. However, recovery was low, so the possibility exists that anhydrite was preferentially not recovered. Zone 3 was observed at a depth of 


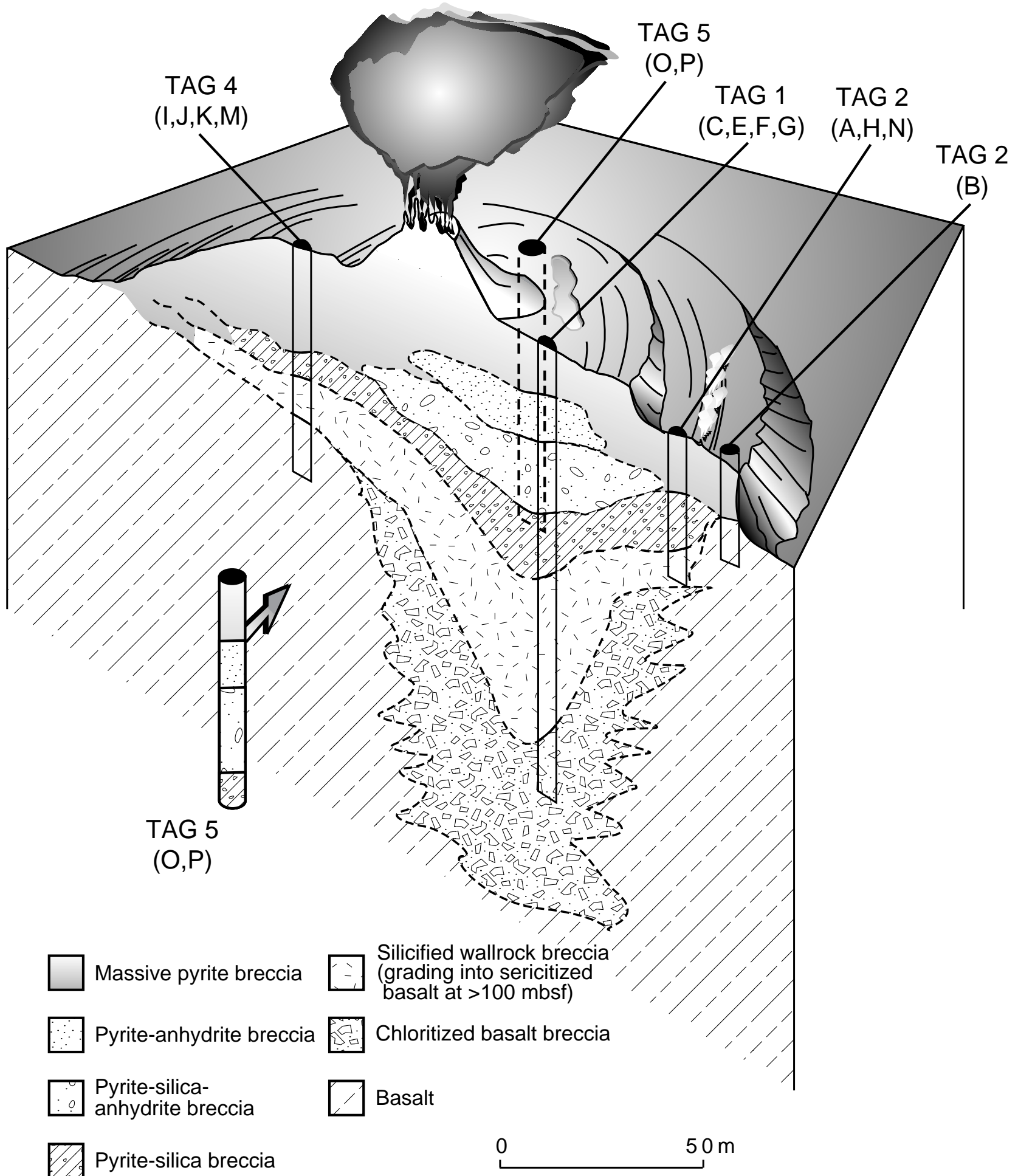

Figure 2. Three-dimensional sketch of the TAG active mound showing the surface morphology and distribution of venting, as well as the generalized and simplified internal structure based on the drilling results (after Humphris et al., 1995). Four major zones within the mound and upflow zone can be distinguished: Zone 1 = massive pyrite breccias: clasts (up to $5 \mathrm{~cm}$ ) of massive, granular pyrite in a porous, sandy pyrite matrix with minor amounts of anhydrite; Zone $2=$ pyrite-anhydrite breccias: down to $\sim 30 \mathrm{mbsf}$-round pyrite clasts $(0.5-2 \mathrm{~cm}$ in size $)$ in a matrix of anhydrite; Zone $3=$ pyrite-silica breccias: large $(<10 \mathrm{~cm})$ gray fragments of siliceous material (pre-existing mineralized and silicified wallrock) and quartz-pyrite clasts in a matrix of fine-grained quartz; Zone $4=$ chloritized basalt breccias occur below about $100 \mathrm{~m}$ : chloritized and weakly mineralized basalt fragments $(1-5 \mathrm{~cm}$ in size) cemented by quartz and pyrite and crosscut by veins of pyrite, quartz, and quartz + pyrite. 
greater than $40 \mathrm{mbsf}$ and is characterized by a quartz-sulfide stockwork. Zone 4 is a quartz-chlorite stockwork, which was sampled at depths greater than 100 mbsf in Hole 957E of the TAG-1 area (Fig. 2 ). This complex structure implies that the TAG active mound has undergone multiple stages of development, which are reflected in the sequences of alteration and veining events that can be distinguished in these breccias (Humphris et al., 1995).

\section{LABORATORY AND ANALYTICAL METHODS}

\section{Paleomagnetic Sampling}

During Leg 158, 46 discrete paleomagnetic samples were taken for shipboard and shore-based paleomagnetic and rock magnetic studies. These $2.5-\mathrm{cm}$ cylindrical samples were drilled from the core sections that contained vertically oriented long pieces, using a watercooled nonmagnetic drill bit attached to a standard drill press. No samples were taken from cores recovered at the TAG-3 area because of the lack of vertically oriented long pieces (note that only the last $12 \mathrm{hr}$ of drilling time were devoted to the TAG-3 area). In all cases, the uphole direction was carefully recorded on the sample by means of an orientation arrow before removal from the core section. All samples were kept in a relatively cold temperature and low-field environment (field-free room) to inhibit water loss and prevent viscous remanence acquisition.

\section{Magnetic Measurement Procedure}

The paleomagnetic and rock magnetic data presented in this paper are of two different types: those obtained using the shipboard passthrough cryogenic magnetometer and those derived from analysis of discrete samples both on ship and on shore. In the shipboard passthrough system, magnetic measurements were performed by passing continuous archive-half core sections through a $2 \mathrm{G}$ cryogenic magnetometer and were taken at intervals of either 5 or $10 \mathrm{~cm}$ along the core, after alternating field (AF) demagnetization at 10- and 15-mT. Whole-core magnetic susceptibility was measured at 3-cm intervals on selected sections using the Bartington susceptibility meter mounted on the multisensor track. Twenty-six samples were stepwise demagnetized using Schonstedt equipment to evaluate the directional stability and coercivity/unblocking temperature spectra of each sample. Because many recovered core sections contain small and unoriented pieces, the limited number of oriented samples for shipboard studies must to be shared among research groups. For this reason, we were able to perform thermal demagnetization on only a pair of samples (pyrite breccia and anhydrite vein, respectively). For these two samples, initial susceptibility was monitored between each temperature step as a means of assessing any irreversible mineralogical changes associated with heating. A vector diagram was used for each sample to identify the magnetic components of magnetization that were present. Magnetic components were determined by fitting leastsquares lines to segments of the vector demagnetization plots or "the principal component analysis" (Zijderveld, 1967; Kirschvink, 1980) that were linear in three-dimensional space.

Rock magnetic measurements of 25 discrete samples in shorebased studies were performed at the paleomagnetism laboratories at the University of California at Santa Cruz and at the Institute for Rock Magnetism of the University of Minnesota. For rock magnetic characterization, samples were subjected to a wide range of magnetic measurements. These included (1) the initial Natural Remanent Magnetization (NRM) measurement followed by two weeks of zero-field storage; (2) remeasurement of NRM; (3) initial susceptibility; (4) Koenigsberger ratio; (5) hysteresis loop parameters: saturation magnetization, $\left(J_{s}\right)$, saturation remanence, $\left(J_{r}\right)$, coercivity, $\left(H_{c}\right)$, remanent coercivity, $\left(H_{c r}\right)$, and paramagnetic susceptibility, $\left(\chi_{\mathrm{p}}\right) ;(6)$ intensity and stability of anhysteretic remanent magnetization (ARM) and acquisition of partial anhysteretic remanent magnetization (pARM); (7) thermomagnetic measurements including low temperature $(5 \mathrm{~K}$ and
$20 \mathrm{~K}$ ) thermal demagnetization of saturation isothermal remanent magnetization and high-temperature (up to $700^{\circ} \mathrm{C}$ ) dependence of the low-field magnetic susceptibility and Curie temperature determination; and (8) Mössbauer spectroscopy and scanning electron microscope (SEM) analysis of representative samples to investigate the overall iron-containing mineralogy. Results of each experiment are given in the section below.

\section{MAGNETIC RESULTS}

The results of Measurements 1 through 6 (see preceding paragraph) are given in Tables 1 and 2. Measurements 7 and 8 will be discussed separately.

\section{Remanence Properties}

Whole-Core Pass-Through Measurement: Natural Remanent Magnetization (NRM) Intensity and Magnetic Susceptibility

Within the four drilling areas (TAG-1, TAG-2, TAG-4, and TAG5) where rock magnetic screening of samples are made, there are considerable variations in magnetic properties and demagnetization behavior among the various lithologies, as will be described in detail below. The most common features, however, can be summarized as follows: a remagnetization imparted by the coring process is commonly encountered as noted during previous legs (e.g., Zhao et al., 1994). This remagnetization is characterized by NRM inclinations that are strongly biased toward vertical value $\left(+90^{\circ}\right)$ in many cores. This remagnetization most severely affected the external portions of the cores (presumably because the outside of the core is physically closer to the magnetized core barrel). As shown in Figure 3, the NRM inclinations observed from Cores $158-957 \mathrm{C}-7 \mathrm{~N}$ and $-11 \mathrm{~N}$ (TAG-1 area) are biased toward steep positive values (with a mean of $68.9^{\circ}$ ), which are significantly higher than that of the expected inclination (about $55^{\circ}$ ) at Site 957, suggesting the presence of drilling-induced remagnetization. Figure 3 also shows that AF demagnetization to 15 $\mathrm{mT}$ is not sufficient to remove this drilling-induced magnetization, as evidenced by virtually no change in mean inclination, although intensity was significantly reduced to one third of its original value. As will be shown below, it appears that only thermal demagnetization can effectively remove this drilling-induced remagnetization and isolate a stable component of magnetization.

In Figure 3, the averaged NRM intensity for sections in Core 158$957 \mathrm{C}-7 \mathrm{~N}$ from the TAG- 1 area is $8.8 \mathrm{~mA} / \mathrm{m}$, but $24.8 \mathrm{~mA} / \mathrm{m}$ for sections from Core $158-957 \mathrm{C}-11 \mathrm{~N}$. This approximately threefold increase in intensity appears to coincide with a change in lithology (from nodular pyrite-anhydrite breccia in Core $158-957 \mathrm{C}-7 \mathrm{~N}$ to pyrite-silica-anhydrite-breccia in Core 158-957C-11N; see Humphris, Herzig, Miller, et al., 1996). A similar example is also found in Core 158-957H-5N of the TAG 2 area (Fig. 4). The average intensity for the upper section (to a depth of $27.45 \mathrm{mbsf}$ ) is $0.8 \mathrm{~mA} / \mathrm{m}$; whereas for the lower section, it is $2.8 \mathrm{~mA} / \mathrm{m}$. This trend of increasing intensity also coincides with changes observed in the lithology (from nodular pyrite-silica breccia in Section $158-957 \mathrm{H}-5 \mathrm{~N}-1$ to silicified basalt breccia in Section $158-957 \mathrm{H}-5 \mathrm{~N}-2$ ). The values of downhole lowfield magnetic susceptibility for Cores $158-957 \mathrm{C}-7 \mathrm{~N}$ through $15 \mathrm{~N}$ are consistently low, averaging about $4 \times 10^{-5}$ SI unit, fully in agreement with the observed relatively weak NRM intensities from these cores (Fig. 3). These low magnetic susceptibility values are also confirmed by results of individual sample susceptibility measurements from minicores listed in Table 1 and obtained using two different instruments that yielded overlapping results.

\section{AF and Thermal Demagnetization of Discrete Samples}

To investigate the nature of the remanent magnetization of the discrete samples from the four TAG areas, selected samples were step-wise AF or thermally demagnetized. The NRM intensity or di- 
Table 1. Remanent magnetic properties of minicore samples from the TAG mound.

\begin{tabular}{|c|c|c|c|c|c|c|c|c|}
\hline $\begin{array}{l}\text { Core, section, } \\
\text { interval }(\mathrm{cm})\end{array}$ & $\begin{array}{l}\text { Depth } \\
\text { (mbsf) }\end{array}$ & Rock & $\begin{array}{c}\mathrm{NRM} \\
(\mathrm{mA} / \mathrm{m})\end{array}$ & $\begin{array}{c}\text { NRM inc } \\
\left({ }^{\circ}\right)\end{array}$ & $\begin{array}{c}\mathrm{ChRM} \text { inc } \\
\left({ }^{\circ}\right)\end{array}$ & $\begin{array}{c}K \\
\left(10^{-6} \mathrm{SI}\right)\end{array}$ & $Q$ ratio & $\begin{array}{l}\mathrm{MDF} \\
(\mathrm{mT})\end{array}$ \\
\hline \multicolumn{9}{|l|}{ TAG-1 area } \\
\hline $957 \mathrm{C}-7 \mathrm{~N}-1,28-30$ & 19.76 & PAB & 7.2 & 70.0 & 68.0 & & & 12 \\
\hline $957 \mathrm{C}-7 \mathrm{~N}-2,66-68$ & 20.87 & PAB & 14.2 & 75.8 & 79.7 & & & 17 \\
\hline $957 \mathrm{C}-7 \mathrm{~N}-2,111-113$ & 21.30 & PAB & 42.7 & 79.0 & 73.0 & & & 18 \\
\hline $957 \mathrm{C}-7 \mathrm{~N}-3,15-17$ & 22.5 & $\mathrm{AV}$ & 7.4 & 71.1 & 72.2 & -2.07 & -10.72 & 65 \\
\hline $957 \mathrm{C}-7 \mathrm{~N}-3,47-49$ & 22.8 & PAB & 18.9 & 72.5 & 70.6 & 35.13 & 1.609 & 19 \\
\hline $957 \mathrm{C}-11 \mathrm{~N}-1,21-23$ & 30.91 & $\mathrm{AV}$ & 11.9 & 76.6 & 61.0 & & & TD \\
\hline $957 \mathrm{C}-11 \mathrm{~N}-1,114-116$ & 31.84 & AV & 13.6 & 69.7 & 50.4 & & & TD \\
\hline $957 \mathrm{C}-11 \mathrm{~N}-2,22-24$ & 30.70 & PSB & 15.9 & 83.9 & & & & \\
\hline $957 \mathrm{C}-11 \mathrm{~N}-3,86-88$ & 34.47 & PSB & 323 & 55.0 & & & & \\
\hline $957 \mathrm{C}-11 \mathrm{~N}-3,118-120$ & 37.67 & PSB & 35.1 & 83.4 & & & & \\
\hline $957 \mathrm{C}-14 \mathrm{~N}-1,18-20$ & 40.18 & PSB & 8.0 & 61.0 & & & & \\
\hline $957 \mathrm{C}-15 \mathrm{~N}-1,115-117$ & 42.94 & PSB & 6.7 & 70.5 & & & & \\
\hline $957 \mathrm{C}-16 \mathrm{~N}-1,8-10$ & 46.28 & PAB & 11.8 & 74.0 & 72.1 & 12.13 & 2.902 & 21 \\
\hline $957 \mathrm{C}-16 \mathrm{~N}-1,17-19$ & 46.35 & PAB & 5.7 & 72.0 & 70.0 & & & 10 \\
\hline $957 \mathrm{C}-16 \mathrm{~N}-2,7-9$ & 47.69 & PSAB & 72.2 & 84.6 & 89.4 & 57.67 & 3.861 & 70 \\
\hline $957 \mathrm{~F}-1 \mathrm{~N}-1,62-64$ & 1.64 & MPB & 5.44 & 53.6 & 51.8 & 75.33 & 2.220 & 12 \\
\hline $957 \mathrm{G}-3 \mathrm{~N}-1,10-12$ & 21.10 & PAB & 243 & -3.0 & & & & \\
\hline $957 \mathrm{G}-3 \mathrm{~N}-1,15-17$ & 21.15 & PAB & 1.84 & 55.5 & 65.1 & 18.33 & 3.094 & 15 \\
\hline \multicolumn{9}{|l|}{ TAG-2 area } \\
\hline $957 \mathrm{H}-5 \mathrm{~N}-1,33-35$ & 27.03 & PSB & 4.46 & 30.5 & 33.1 & 84.13 & 1.585 & 19 \\
\hline $957 \mathrm{H}-5 \mathrm{~N}-2,29-31$ & 27.89 & SBB & 19.1 & 86.5 & 84.8 & 65.13 & 8.770 & 13 \\
\hline $957 \mathrm{H}-5 \mathrm{~N}-2,72-74$ & 28.30 & SBB & 20.1 & 80.0 & 72.0 & & & 11 \\
\hline \multicolumn{9}{|l|}{ TAG-4 area } \\
\hline $957 \mathrm{M}-9 \mathrm{R}-1,61-63$ & 42.91 & BAS & $3.82 \mathrm{E} 4$ & 47.1 & 14.1 & 24940 & 45.92 & 6 \\
\hline $957 \mathrm{M}-10 \mathrm{R}-1,26-28$ & 46.48 & BAS & $1.02 \mathrm{E} 4$ & 70.3 & 35.9 & & & 11 \\
\hline 957M-10R-1,35-37 & 46.55 & BAS & $1.59 \mathrm{E} 4$ & 36.2 & 13.9 & 18030 & 26.37 & 20 \\
\hline 957M-10R-1,89-91 & 47.07 & BAS & $1.73 \mathrm{E} 4$ & 18.0 & 18.8 & & & 21 \\
\hline $957 \mathrm{M}-10 \mathrm{R}-1,102-104$ & 47.16 & BAS & $1.25 \mathrm{E} 4$ & 18.0 & 21.4 & & & 18 \\
\hline \multicolumn{9}{|l|}{ TAG-5 area } \\
\hline $957 \mathrm{O}-2 \mathrm{R}-1,34-36$ & 8.24 & PB & 14.90 & 39.0 & 56.8 & 72.67 & 6.131 & 11 \\
\hline $957 \mathrm{O}-2 \mathrm{R}-1,37-39$ & 8.25 & PB & 8.93 & 58.2 & 62.1 & 71.67 & 3.726 & 45 \\
\hline 957O-4R-1, 29-31 & 16.19 & PAB & 27.5 & 72.5 & 80.1 & 109.0 & 7.545 & 9 \\
\hline $957 \mathrm{O}-4 \mathrm{R}-1,30-32$ & 16.20 & PAB & 18.6 & 81.0 & 72.0 & & & 11 \\
\hline $957 \mathrm{P}-9 \mathrm{R}-1,4-6$ & 40.14 & MPB & 10.2 & 49.0 & & 47.33 & 6.445 & 12 \\
\hline
\end{tabular}

Note: $\mathrm{SBB}=$ silicified basalt breccia, $\mathrm{BAS}=$ basalts, $\mathrm{PB}=$ pyrite breccia, $\mathrm{PAB}=$ pyrite anhydrite breccia, $\mathrm{MPB}=$ massive pyrite breccia, $\mathrm{AV}=$ anhydrite vein, $\mathrm{PSAB}=$ pyrite-silicaanhydrite-breccia, $\mathrm{PSB}=$ pyrite-silica-breccia, $\mathrm{NRM}=\mathrm{NRM}$ intensity, NRM inc. $=\mathrm{NRM}$ inclination, ChRM inc. $=$ characteristic remanent magnetization inclination, $K=$ lowfield magnetic susceptibility, $Q$ ratio = Koenigsberger ratio, $\mathrm{MDF}=$ median demagnetizing field.

Table 2. Hysteresis properties of minicore samples from the TAG mound.

\begin{tabular}{|c|c|c|c|c|c|c|c|c|}
\hline Core, section, interval $(\mathrm{cm})$ & $\begin{array}{l}\text { Depth } \\
\text { (mbsf) }\end{array}$ & Rock & $\begin{array}{l}\mathrm{ARM} \\
(\mathrm{mA} / \mathrm{m})\end{array}$ & $\mathrm{MDF}_{\mathrm{a}}$ & $\mathrm{MDF}_{\mathrm{a}} / \mathrm{MDF}$ & $M_{r} / M_{s}$ & $H_{c r} / H_{c}$ & $\chi_{\mathrm{p}}$ \\
\hline \multicolumn{9}{|l|}{ TAG-1 area } \\
\hline $957 \mathrm{C}-7 \mathrm{~N}-3,37-39$ & 22.72 & AV & & & & 0.119 & 3.95 & 0.008 \\
\hline $957 \mathrm{C}-7 \mathrm{~N}-2,111-113$ & 21.96 & PAB & 3.17 & 20 & 1.3 & & & \\
\hline $957 \mathrm{C}-1 \mathrm{~N}-1,28-30$ & 19.78 & $\mathrm{AV}$ & 50.4 & & & & & \\
\hline $957 \mathrm{C}-11 \mathrm{~N}-3,86-88$ & 34.47 & PSB & 649 & 17 & & & & \\
\hline $957 \mathrm{C}-16 \mathrm{~N}-1,17-19$ & 46.37 & PAB & 5.96 & 70 & 3.5 & 0.149 & 5.55 & 2.6 \\
\hline $957 \mathrm{~F}-1 \mathrm{~N}-1,51-53$ & 1.51 & MPB & & & & 0.123 & 4.58 & 12.8 \\
\hline $957 \mathrm{G}-3 \mathrm{~N}-1,48-50$ & 21.48 & PAB & & & & 0.063 & 4.71 & 3.5 \\
\hline \multicolumn{9}{|l|}{ TAG-2 area } \\
\hline $957 \mathrm{H}-5 \mathrm{~N}-1,32-34$ & 27.02 & PSB & & & & 0.123 & 3.04 & 0.83 \\
\hline $957 \mathrm{H}-5 \mathrm{~N}-2,72-74$ & 28.32 & SBB & 46 & & & 0.222 & 3.04 & 0.05 \\
\hline \multicolumn{9}{|l|}{ TAG-4 area } \\
\hline 957M-10R-1, 35-37 & 46.55 & BAS & & & & 0.323 & 1.65 & 3.73 \\
\hline 957M-10R-1, 89-91 & 47.09 & BAS & $2.9 \mathrm{E} 4$ & 65 & 2.95 & 0.248 & 1.92 & 4.5 \\
\hline 957M-10R-1, 102-104 & 47.22 & BAS & $1.8 \mathrm{E} 4$ & & & & & \\
\hline $957 \mathrm{M}-10 \mathrm{R}-1,26-28$ & 46.46 & BAS & $2.5 \mathrm{E} 4$ & & & & & \\
\hline $957 \mathrm{M}-5 \mathrm{R}-1,43-45$ & 24.73 & $\mathrm{~PB}$ & & & & 0.161 & 3.69 & 0.045 \\
\hline \multicolumn{9}{|l|}{ TAG-5 area } \\
\hline 957O-4R-1, 30-32 & 16.20 & PAB & 5.66 & 32 & 2.13 & 0.099 & 2.62 & 0.049 \\
\hline
\end{tabular}

Note: $\mathrm{SBB}=$ silicified basalt breccia, $\mathrm{BAS}=$ basalts, $\mathrm{PB}=$ pyrite breccia, $\mathrm{PAB}=$ pyrite anhydrite breccia, $\mathrm{MPB}=$ massive pyrite breccia, $\mathrm{AV}=$ anhydrite vein, $\mathrm{PSAB}=$ pyrite-silicaanhydrite-breccia, $\mathrm{PSB}=$ pyrite-silica-breccia. $\mathrm{ARM}$ is in $\mathrm{mA} / \mathrm{m}, \mathrm{MDF}_{\mathrm{a}}$ is the median demagnetizing field of ARM in Oe. See text for the explanations of other symbols.

rection of the minicores did not change significantly $(<5 \%)$ after zero-field storage for two weeks. As mentioned above, the vertically directed, drilling-induced magnetization is often present in Leg 158 cores. In most cases, this steeply downward component of magnetization is very resistant to AF demagnetization (see Fig. 5 for an example). In other cases, however, thermal demagnetization of a pair of samples (pyrite breccia and anhydrite vein, respectively) successfully removed this drilling-induced magnetization component. As shown in Figure 6A, the drilling-induced remagnetization component (with inclination greater than $75^{\circ}$ ) is removed after $300^{\circ} \mathrm{C}$ demagnetization and a characteristic component (with inclination around $50^{\circ}$ ) can be identified. It is interesting to note that both the pyrite breccia (Sample $158-957 \mathrm{C}-11 \mathrm{~N}-1,114-116 \mathrm{~cm}$ ) and the anhydrite vein (Sample 158957C-11N-1, 21-23 cm) displayed similar demagnetization behaviors, with unblocking temperatures close to $350^{\circ} \mathrm{C}$. As mentioned, we used magnetic susceptibility to monitor the production of new magnetic materials during thermal demagnetization that might have altered the remanence. Apart from small insignificant fluctuations, the susceptibility of the two samples generally did not change until after they had been heated to $350^{\circ} \mathrm{C}$. Above this temperature, the two sam- 


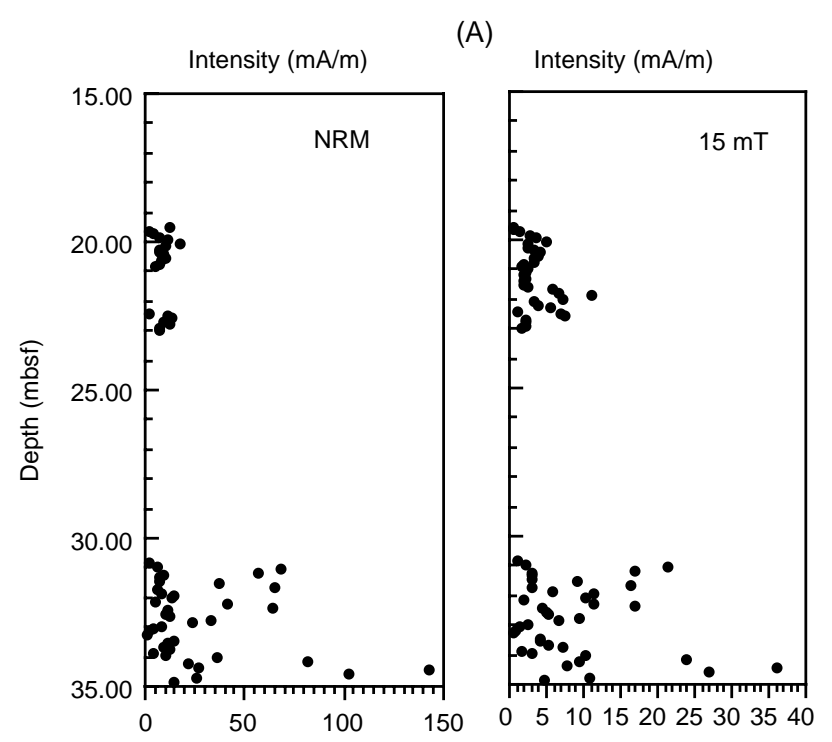

(B)

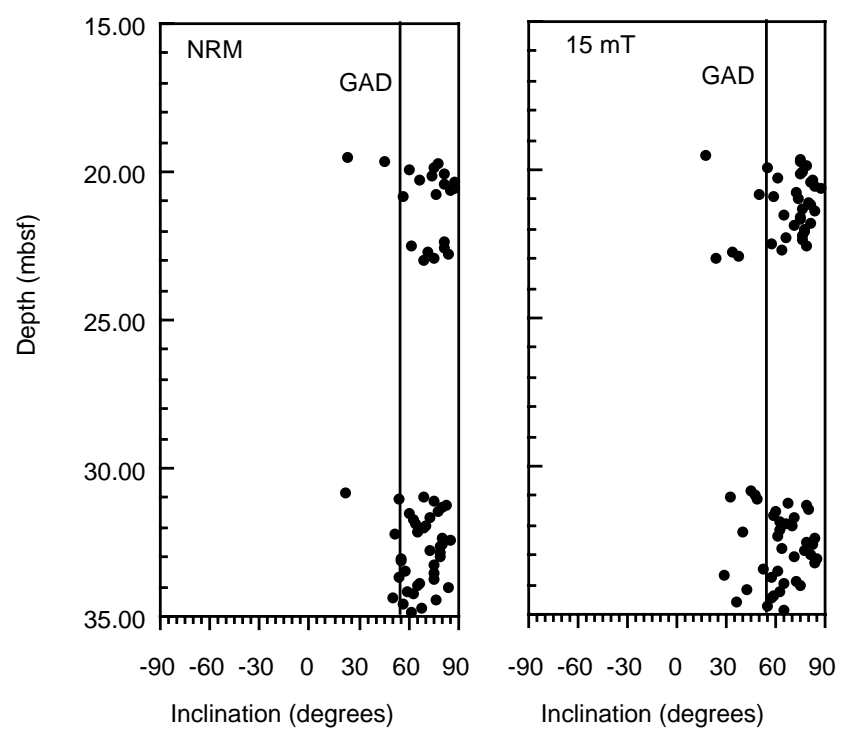

Figure 3. Remanent magnetization before and after 15-mT AF demagnetization as a function of sub-bottom depth. Intensities (A) and inclinations (B) of archive halves from Cores $158-957 \mathrm{C}-5 \mathrm{~N}$ and $11 \mathrm{~N}$ are shown. The NRM inclinations are strongly biased toward high positive inclinations, suggesting that drilling-induced magnetization is present. $\mathrm{AF}$ demagnetization to $15 \mathrm{mT}$ could not effectively remove this drilling-induced magnetization, as indicated by the insignificant changes in inclination. The expected inclination value $\left(55^{\circ}\right)$ of geocentric dipole field $(\mathrm{GAD})$ is shown by a vertical line.

ples showed a decrease in susceptibility. It is worth pointing out that this temperature coincides with the high-temperature fluids $\left(350^{\circ}-\right.$ $400^{\circ} \mathrm{C}$ ) that are actively circulating the TAG site (Tivey et al., 1995).

Results from AF demagnetization of five basalt samples from the TAG-4 area (Fig. 7) show behavior that cannot be interpreted in such a simple fashion. As shown in Figure 7, some of these samples exhibited signs of drilling-induced magnetization as evidenced by the steep inclinations in the initial demagnetization measurements, but AF demagnetization to $10 \mathrm{mT}$ effectively removed this overprint. Although only five samples were measured, it seems reasonable to conclude that drilling has had a lesser effect on the NRM of these basalt samples as compared with that of sulfide cores. It is interesting to note that the stable component for these samples has a much shallower in-

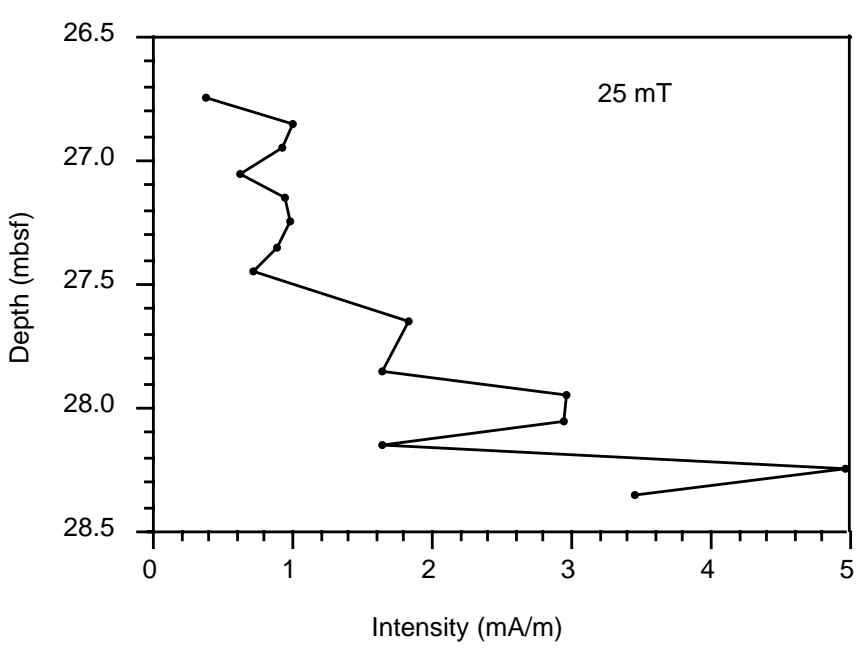

Figure 4. The downhole variation of intensity of NRM after alternating-field (AF) demagnetization at $25 \mathrm{mT}$ for Core $158-957 \mathrm{H}-5 \mathrm{~N}$ (the TAG-2 area).

clination $\left(14^{\circ}-36^{\circ}\right.$, with a mean value of $\left.20.8^{\circ}\right)$ compared to the expected inclination $\left(55^{\circ}\right)$ at the drilling site, suggesting that either the section has been tilted or that magnetization may have been affected by the hydrothermal alteration that occurred at the TAG mound, or both.

\section{Koenigsberger Ratio}

The Koenigsberger ratio Q is defined as the ratio in a rock of remanent magnetization to the induced magnetization in the Earth's field. In general, the Koenigsberger ratio is used as measure of stability to indicate a rock's capability of maintaining a stable remanence. The International Geomagnetic Reference Field (IGRF) value at the TAG site $(42,000 \mathrm{nT}=33.44 \mathrm{~A} / \mathrm{m})$ was used for calculating $Q$, where $Q=\mathrm{NRM}[\mathrm{A} / \mathrm{m}] /(k[\mathrm{SI}] \times H[\mathrm{~A} / \mathrm{m}]$, and $H$ is the local geomagnetic field. The variation of the Koenigsberger ratios in Table 1 in general resembles that of the NRM. For example, the silicified basalt breccia, Sample $158-957 \mathrm{H}-5 \mathrm{~N}-2,29-31 \mathrm{~cm}$, from the TAG-2 area has a higher intensity of remanence than the nodular pyrite-silica breccia Sample $158-957 \mathrm{H}-5 \mathrm{~N}-1,33-35 \mathrm{~cm}$, and consequently the Koenigsberger ratio of the former is higher than that of the later. Similar examples of this correlation are also seen in samples from other TAG areas. The Koenigsberger ratio is generally greater than 1.0 with only one exception from the TAG-1 area (Sample 158-957C-7N-3, 15-17 cm) taken from an anhydrite vein, which is diamagnetic (see the "Hysteresis Properties" section below for more discussion of this sample). The Koenigsberger ratios for two samples (Sample 158-957C-7N-3, $47-49 \mathrm{~cm}$ from the TAG-1 area and Sample 158-957H-5N-1, 33-35 $\mathrm{cm}$ from the TAG-2 area) are slightly greater than 1.0, indicating that induced magnetization would be comparable to that of remanent magnetization. The low value of the Koenigsberger ratio for these two samples also indicates the presence of low-coercivity magnetic minerals that carry an unstable remanence and are more susceptible to an external magnetic field.

\section{Low-Field Magnetic Susceptibility}

Volume magnetic susceptibility of natural materials in a weak magnetic field depends on the abundance and grain size of ferromagnetic minerals. Discrete samples of sulfide breccias show magnetic susceptibility values from $1.0 \times 10^{-4}$ to $1.1 \times 10^{-4}$ SI unit, with an average of $5.0 \times 10^{-4} \mathrm{SI}$, indicating a very low concentration of ferro(i)magnetic minerals in these sulfides. It is of interest to note that these susceptibility values are of the same order as that of pyrrhotite 
Sample $158-957 \mathrm{~F}-1 \mathrm{~N}-1,62-64 \mathrm{~cm}$

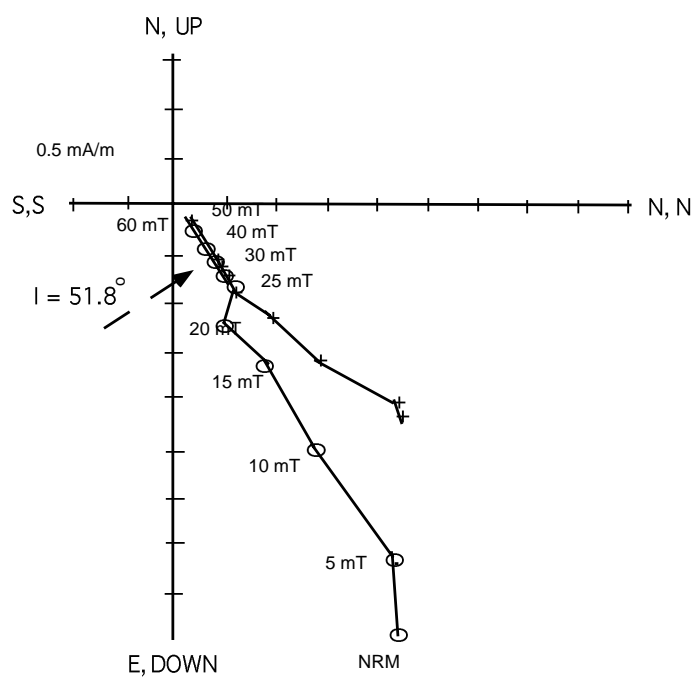

A
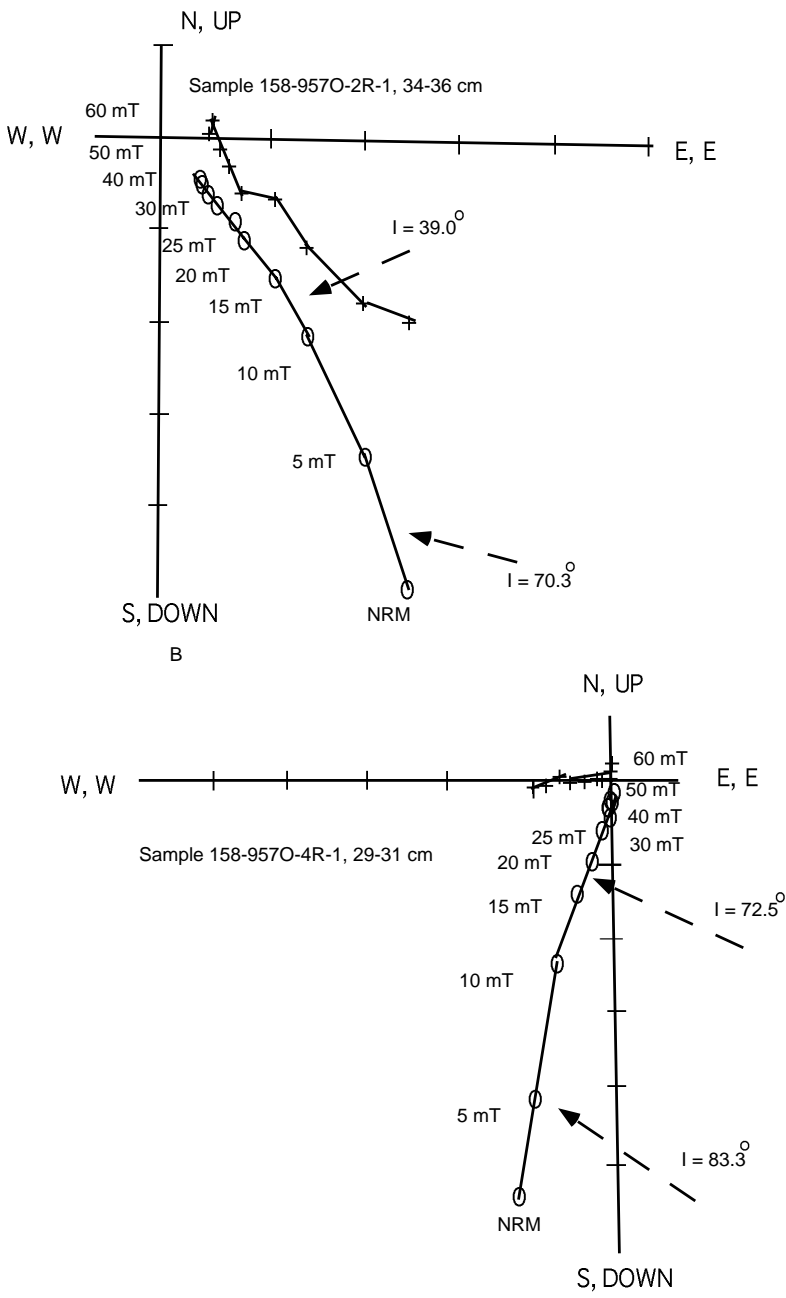

Figure 5. Representative vector endpoint diagrams showing the results of AF demagnetization for representative discrete samples from the TAG drilling areas: (A) TAG-1; (B) and (C) TAG-5. The magnetic component is shown by a straight line fitting the data points, and the corresponding inclination (I) is indicated. Open circles and crosses represent vector endpoints projected onto the vertical and horizontal planes, respectively. with pseudo-single domain grain size (Dekkers, 1988). The susceptibility of basalt samples from the TAG-4 area, on the other hand, is much higher than those of the sulfides, averaging $215.0 \times 10^{-4} \mathrm{SI}$. This is expected because they are known to have very different magnetic mineralogies.

\section{Anhysteretic Remanent Magnetization (ARM)}

ARM is laboratory-induced remanence and is thought to provide insight into the origin of magnetization in these rocks. The manner in which anhysteretic remanent magnetization is acquired and demagnetized also provides information on the type of magnetic carriers and the coercivity spectrum of the sample. After AF demagnetization, the acquisition behavior of ARM was studied for nine samples. The ARM was imparted to the samples in a single axis, metalshielded Schonstedt GSD-1 demagnetizer in an alternating field of $100 \mathrm{mT}$ and a direct current (DC) field of $50 \mu \mathrm{T}$. The ARM was then $\mathrm{AF}$ demagnetized so that the demagnetization behavior could be compared to that of the NRM. The stability of ARM to AF demagnetization is similar to that of the NRM for most of the samples. As listed in Table 2, ARM intensities behave like NRM intensity in general: high in the basalt and low in anhydrite breccia. The other parameter measured is the median demagnetizing field (MDF), which represents the stability of remanence. Unlike intensity of remanence, MDF is only weakly dependent on the inducing field. In comparison, the median demagnetizing field of $\mathrm{ARM}\left(\mathrm{MDF}_{\mathrm{a}}\right)$ is consistently, and sometimes substantially, larger than the median demagnetizing field of NRM, with the ratio varying from 1.3 to 3.5. The differences in these two MDFs may be explained by the substantial secondary components in the NRM of samples.

\section{Hysteresis Loop Parameters \\ Rock Magnetic Properties}

Hysteresis loop parameters are useful in characterizing the intrinsic magnetic behavior of rocks. Thus, they are helpful in studying the origin of remanence. Hysteresis behavior was studied in 12 individual samples. For each sample, hysteresis loops and the associated parameters $M_{r s} M_{s}, H_{c}$, and $H_{c r}$ (remanent coercive force) were obtained at University of California Santa Cruz using an alternating gradient magnetometer (AGFM; Princeton Measurements Corporation) capable of resolving magnetic moments as small as $5 \times 10^{-8} \mathrm{emu}$ (Flanders, 1988). Hysteresis parameters determined from the 11 samples from Hole 957 are presented in Table 2.

Saturation magnetization is a measure of the total amount of magnetic mineral in the sample. The coercivity, $H_{c}$, is a measure of magnetic stability. The two ratios, $J_{r} / J_{s}$ and $H_{c r} / H_{c}$, are commonly used as indicators of domain state and, indirectly, grain size. For magnetite, high values of $J_{r} / J_{s}(>0.5)$ indicate small $(<0.1 \mu \mathrm{m}$ or so) singledomain $(\mathrm{SD})$ gains, and low values $(<0.1)$ are characteristic of large $(>15-20 \mu \mathrm{m})$ multidomain grains (MD). The intermediate regions are usually referred to as pseudo-single domain (PSD). $H_{c r} / H_{c}$ is a much less reliable parameter, but conventionally $\mathrm{SD}$ grains have a value close to 1.1, and MD grains should have values >3-4 (Day et al., 1977). Figure 8 displays the ratios of the hysteresis parameters for four samples containing mainly titanomagnetite as magnetic mineral plotted on a Day and others (1977) type diagram. Such a representation provides qualitative information on the magnetic grain sizes from single domain (SD) to pseudo-single domain (PSD) to large multidomain (MD). The samples analyzed in this study indicate that the magnetic grain sizes of the TAG-4 area fall near the boundary between SD and PSD, whereas the sample from the TAG-2 area is in the pseudo-single domain range.

Paramagnetic susceptibility, $\chi_{\mathrm{p}}$, is the susceptibility of the sample in a magnetic field sufficient to saturate the ferromagnetic component. Hence, it is a function of all the minerals in the rock and is probably more reflective of the more abundant diamagnetic material. As 
Figure 6. Representative vector endpoint diagram showing the results of thermal demagnetization of the pyrite breccia sample (Sample 158-957C-11N-1, 114$116 \mathrm{~cm}$ ), and the anhydrite vein sample (Sample 158$957 \mathrm{C}-11 \mathrm{~N}-1,21-23 \mathrm{~cm}$ ). Two components of magnetization are shown by straight lines fitting the data points. Open circles and crosses represent vector endpoints projected onto the vertical and horizontal planes, respectively.
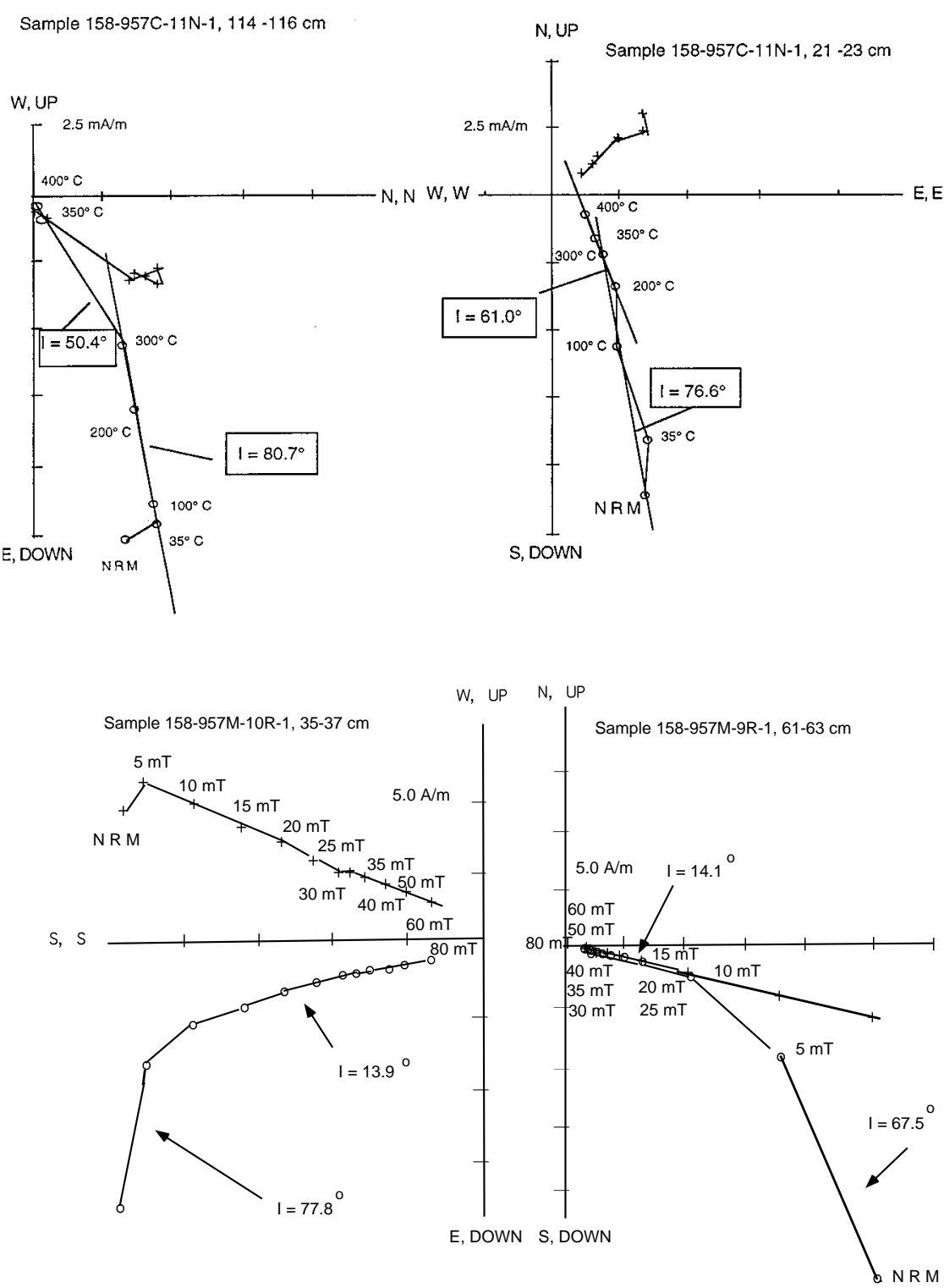

Figure 7. Vector endpoint diagram showing the results of alternating field demagnetization for discrete basalt samples from Cores 158-957M-9R and 10R. The magnetic components are shown by straight lines fitting the data points and the corresponding inclination (I) is indicated. Open circles and crosses represent vector endpoints projected onto the vertical and horizontal planes, respectively. critical value $25 k T / K$ (where $k=$ Boltzmann's constant, $T=300 \mathrm{~K}$ in this study, and $K=$ the magnetic anisotropy constant per unit volume), so that its net remanence over $100 \mathrm{sec}$ is zero (Cullity, 1972). However, as $\mathrm{T}$ is decreased to $0 \mathrm{~K}$, the thermal energy $k T$ decreases and $K$ increases (both serving to aid magnetic stability), so that all grains which were superparamagnetic at $300 \mathrm{~K}$ will be able to retain thermally stable remanent magnetization near $0 \mathrm{~K}$ (Banerjee et al., 1993). In this study, these experiments included (1) cooling the sample from room temperature $(300 \mathrm{~K}$ ) down to $20 \mathrm{~K}$ (in some cases to $5 \mathrm{~K}$ ) in a steady magnetic field of $2.5 \mathrm{~T}$ and measuring the remanence at $5 \mathrm{~K}$ intervals; (2) measuring the saturation isothermal remanence at $5 \mathrm{~K}$ and $20 \mathrm{~K}\left(\mathrm{SIRM}_{5}\right.$ and $\mathrm{SIRM}_{20}$, respectively) and then warming it to $300 \mathrm{~K}$ in zero field while measuring the remanence value every $5 \mathrm{~K}$.

As shown in Figure 9, the low-temperature curves of SIRM both in zero field warming and in a $2.5 \mathrm{~T}$ field cooling display a variety of features. These include an unblocking temperature in the vicinity of $40 \mathrm{~K}$ most likely caused by pyrrhotite (Dekkers et al, 1989; Rochette et al., 1990); a decrease in remanence in the 100-120 K range, most likely caused by the magnetocrystalline anisotropy constant, $k_{l}$, of magnetite going to zero in this temperature, known as the Verwey 


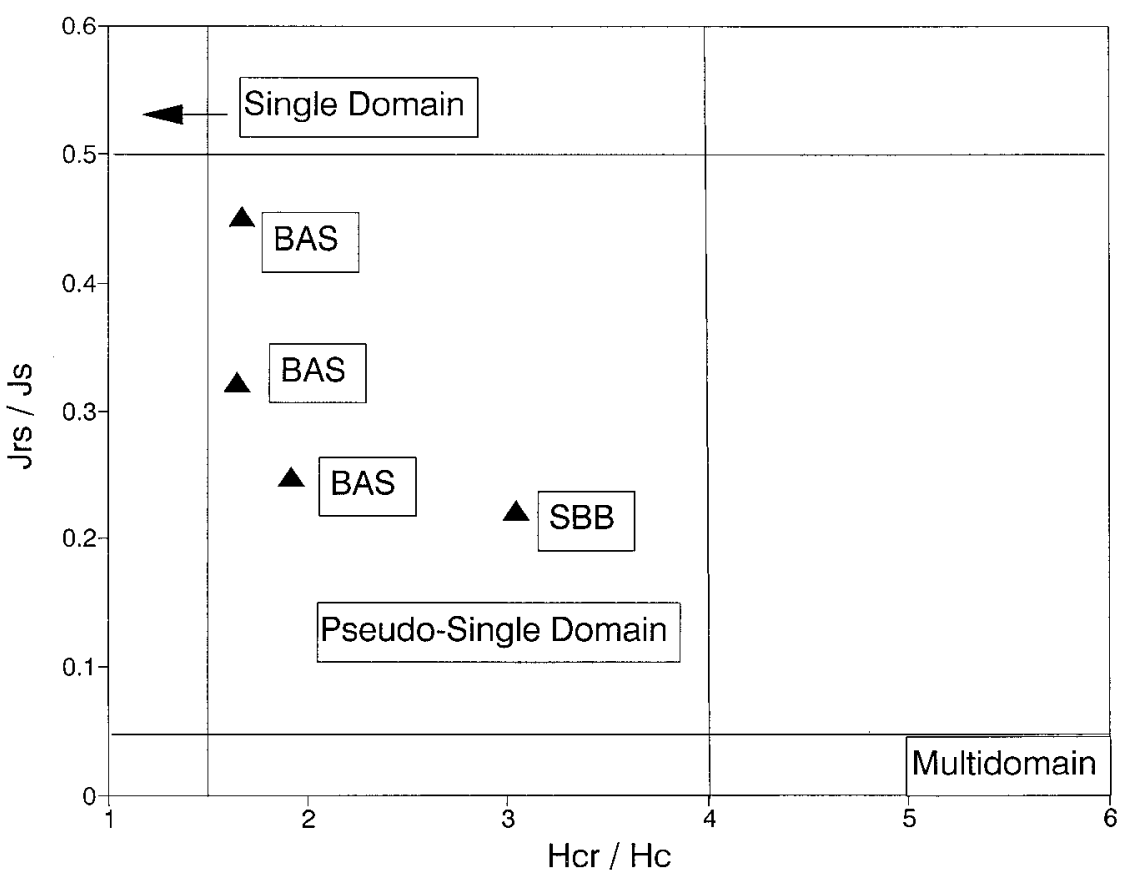

Figure 8 . The hysteresis ratios plotted on a Day et al. (1977) type diagram suggest that the bulk magnetic grain size is in the pseudo-single-domain region. $J_{S}$ is saturation magnetization, $J_{r s}$ is saturation remanent magnetization, $H_{c}$ is coercivity, and $H_{c r}$ is remanent coercive force. Abbreviations are same as in Table 1: $\mathrm{BAS}=$ basalts, $\mathrm{SBB}=$ silicified basalt breccia. transition (Verwey et al., 1947). The low-temperature phase transitions were also detected as a singular point of finite difference (derivative of emu $/{ }^{\circ} \mathrm{K}$, see Fig. 9F). As we shall discuss later, the low-temperature data are one of the major lines of evidence for the presence of pyrrhotite in sulfide samples.

\section{Curie Temperature}

Curie temperature is the temperature below which a magnetic mineral is magnetically ordered. Because this value is a sensitive indicator of composition, it is useful in understanding the magnetic mineralogy. In this study, Curie temperature was determined by measurement of magnetic susceptibility vs. temperature (using the Kappabridge susceptometer at the University of Minnesota), because the susceptibility drops to zero about the Curie temperature. We conducted thermomagnetic analyses in an inert atmosphere on 10 samples chosen to be representative of the Leg 158 cores.

Figure 10 shows high-temperature susceptibility runs of a representative sulfide and a basalt sample. The heating and cooling curves for the sulfide sample display a significant peak of susceptibility around $320^{\circ} \mathrm{C}$ (Fig. 10A). These peaks may be indicative of a fraction of monoclinic pyrrhotite that could be responsible for the observed remanent magnetization. Several new magnetic signatures were also revealed on the cooling curve. The gradual rise in susceptibility around $570^{\circ} \mathrm{C}$ (Fig. 10A) indicates that the pyrrhotite probably was altered into fraction of magnetite after heating to $700^{\circ} \mathrm{C}$ in an argon atmosphere, as reported by previous workers (Schwarz, 1965; Dekkers, 1988).

For the basalt samples recovered from the TAG-4 area, the results show Curie temperatures between $500^{\circ}$ and $540^{\circ} \mathrm{C}$, indicative of the presence of low-Ti titanomagnetite (Fig. 10B). Unoxidized titanomagnetite of normal basalts (with about $62 \%$ ulvospinel and 38\% magnetite in solid solution) has a Curie temperature of approximately $160^{\circ} \mathrm{C}$ and completely oxidized titanomaghemite has a maximum Curie temperature of about $400^{\circ} \mathrm{C}$ (O'Reilly, 1984; Johnson and Hall, 1978; Johnson and Pariso, 1993). The Curie temperature measurements in this study would suggest that while high-temperature oxidation is not common in submarine basalt (Johnson and Hall, 1978), it can sometimes occur with deuteric alteration associated with veining or in some massive flow units.

\section{Mössbauer Effect Spectrometry and Oxide Petrographic Observation}

Two samples were selected for Mössbauer effect investigation to provide more definitive means of identifying magnetic carriers in the sulfide deposit in the TAG hydrothermal mound. Measurements were taken at room temperature using a ${ }^{57} \mathrm{Co}$ in rhodium source and a constant acceleration spectrometer. A crushed sample (roughly $0.5 \mathrm{~g}$ in powder form) was packed into a polythene sample holder with a cross-sectional area of approximately $1 \mathrm{~cm}^{2}$.

The Mössbauer spectra obtained for two samples reflecting extremes in Leg 158 core type are distinct (Fig. 11). The spectrum of a basalt sample from the TAG-4 area (Sample 158-957M-10R-1, 89$91 \mathrm{~cm}$ ) is shown in Figure 11A. At room temperature, the spectrum is dominated by three magnetically ordered components that have been interpreted as being hematite, maghemite, and magnetite, respectively. The magnetite spectrum contains two components, one corresponding to the $\mathrm{A}$ site $\mathrm{Fe}^{3+}$ and the other to the $\mathrm{B}$ site. Figure $11 \mathrm{~B}$ shows the spectrum of a sulfide sample from the TAG- 5 area (Sample 158-957O-4R-1, 30-32 cm) together with fitted curves. The values of the fitting parameters for this spectrum suggest two components that can be identified as pyrite and chalcopyrite, respectively.

Several selected samples were also studied by optical microscopes and by a JEOL JSM 6400 scanning electron microscope (SEM) to examine their oxidation state and the bulk titanomagnetite content. The photomicrography of the basalt sample from the TAG4 area (Sample 158-957M-10R-1, 89-91 cm) exhibits abundant titanomagnetite with typical grain-size less than $5 \mu \mathrm{m}$ (Figs. 12A, 12B, and $12 \mathrm{C}$ ), fully consistent with the Mössbauer spectra results and the grain-size estimate inferred from the hysteresis parameters. An example of chalcopyrite inclusion in a pyrite crystal (Sample 158957C-16N-1, 17-19 cm from the TAG-1 area) is shown in Figure $12 \mathrm{D}$.

\section{DISCUSSION}

The results described above have revealed important information about the origin of remanence and on the magnetic minerals present in the Leg 158 cores, which in turn provide physical insight into the nature of the hydrothermal alteration regime at the TAG field. 

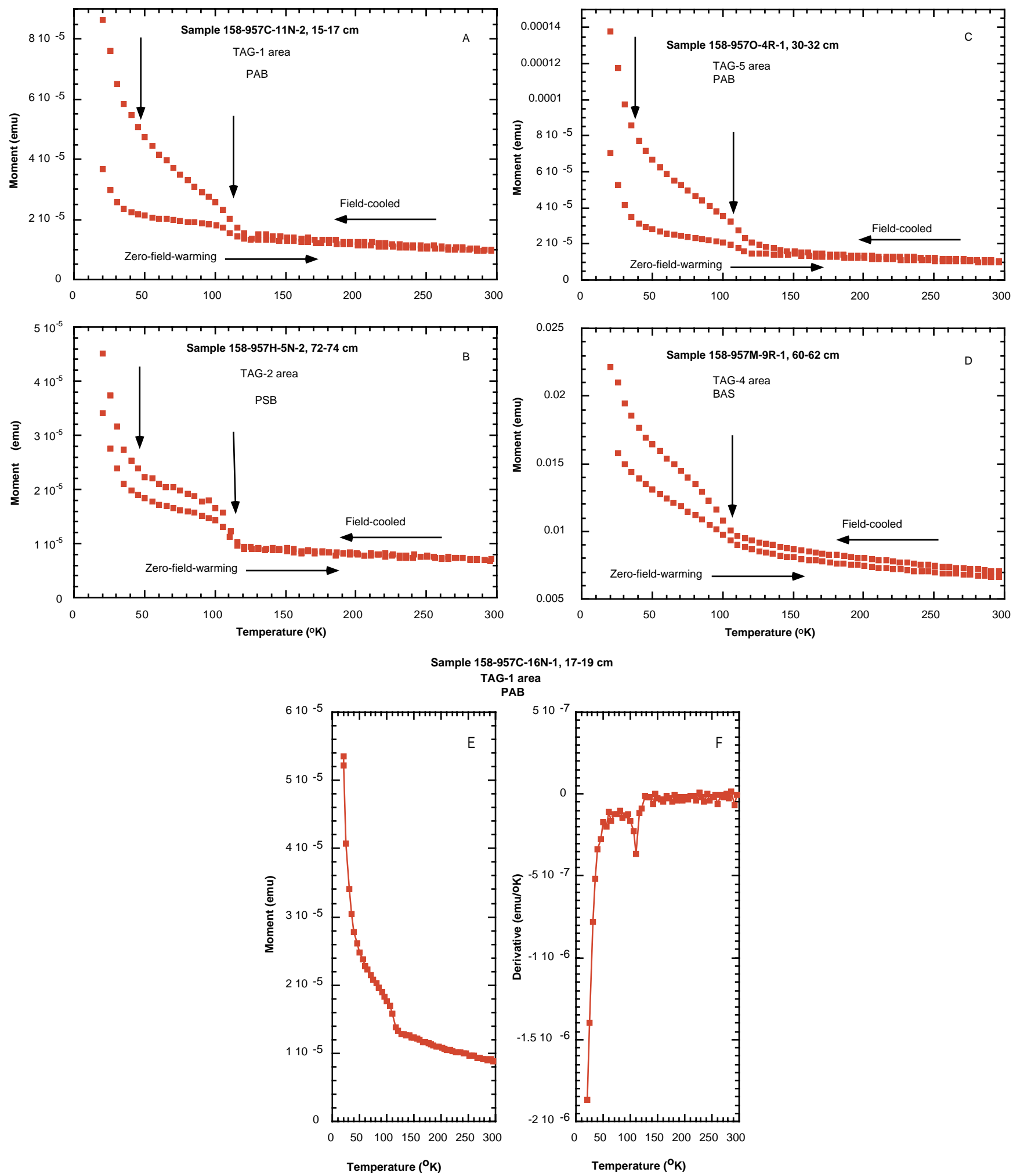

TAG-1 are

PAB

$510-7$

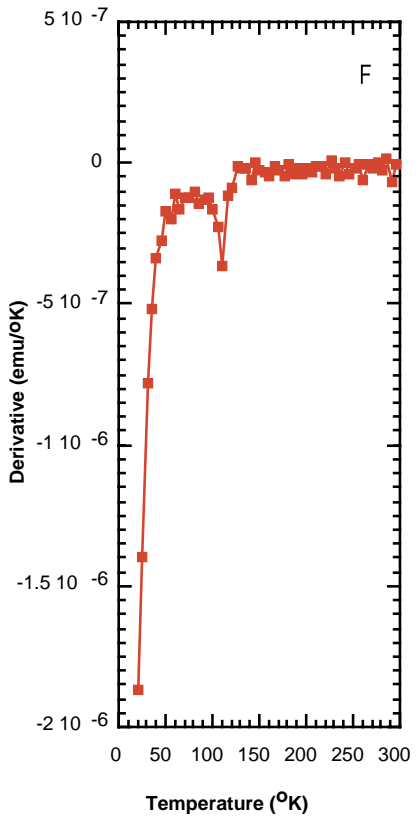

Figure 9. Low-temperature heating curves of saturation remanence normalized to $20 \mathrm{~K}\left(\mathrm{SIRM}_{20}\right)$ both after cooling in zero field and after cooling in a 2.5 field for several representative samples. The change in slope near $100 \mathrm{~K}$ is a result of the Verwey transition in magnetite while the contribution to remanence that is demagnetized at $<50 \mathrm{~K}$ is likely from pyrrhotite $(35-40 \mathrm{~K}$ ). A. Pyrite breccia sample (Sample $158-957 \mathrm{H}-5 \mathrm{~N}-2,72-74 \mathrm{~cm}$ ) from the TAG-1 area. B. Pyrite silica breccia sample (Sample 158-957H-5N-2, 72-74 cm) from the TAG-2 area. C. Pyrite breccia sample (Sample 158-957O-4R-1, 30-32 cm) from the TAG-5 area. D. Basalt sample (Sample 158-957M-9R-1, 60-62 cm) from the TAG-4 area. E. Thermal demagnetization of an IRM (imparted at $20 \mathrm{~K}$ with a $1.0 \mathrm{~T}$ direct field) for pyrite anhydrite breccia sample (Sample 158-957C-16N-1, 17-19 cm) from the TAG-1 area during zero-field warming. F. Finite difference to indicate magnetic phase transition at $120 \mathrm{~K}$ (magnetite) for the pyrite anhydrite breccia sample (Sample 158-957C-16N-1, 17-19 cm) from the TAG-1 area. 
A

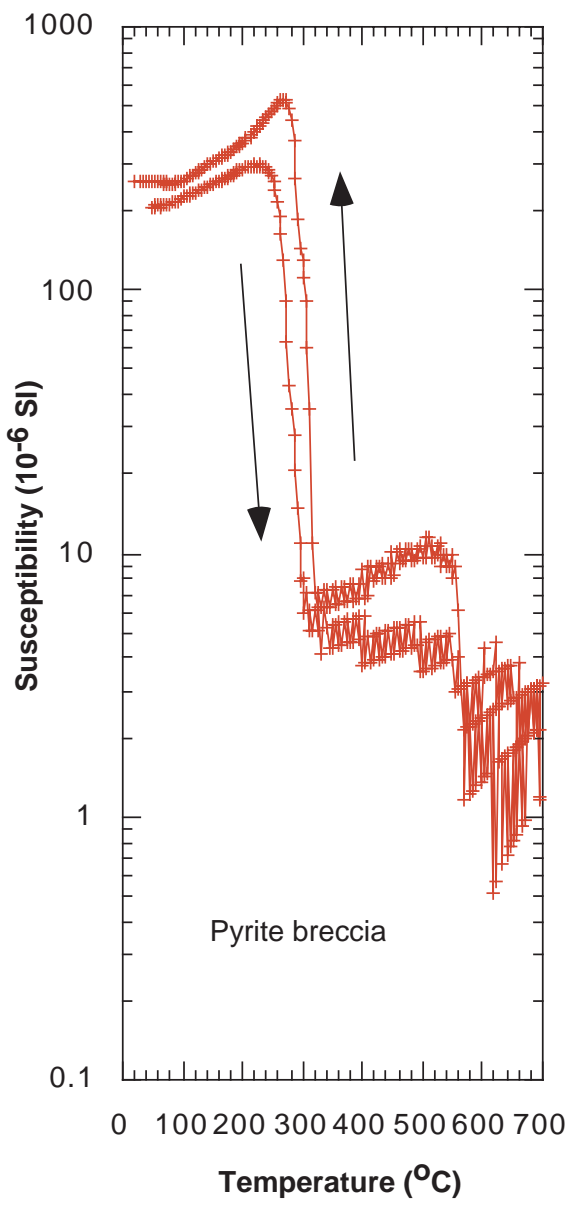

B

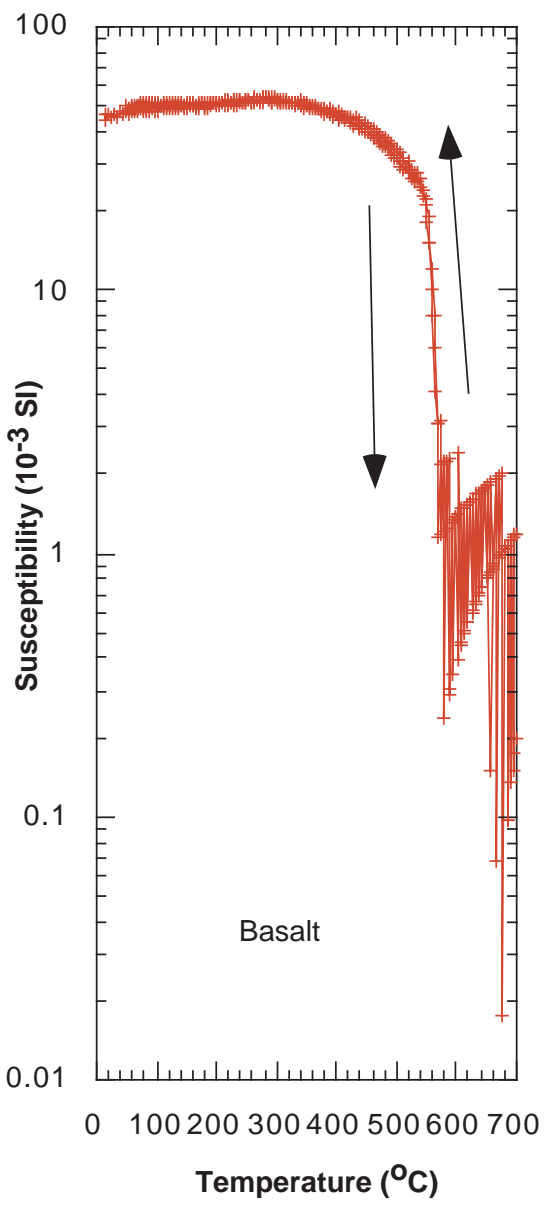

Figure 10. Typical thermomagnetic curves for Leg 158 cores. A. Pyrite breccia sample (Sample 158-957H$5 \mathrm{~N}-2,72-74 \mathrm{~cm}$ ). B. Basalt sample (Sample 158957M-9R-1, 60-62 cm).
The Leg 158 cores recovered from the four TAG drilling areas displayed a multicomponent nature of magnetization. No reversed magnetization was observed, which is expected, as the mound was formed within the last $140 \mathrm{ka}$ (i.e., within the Brunhes normal chron). The steep, positive drilling-induced component is evident in almost all samples. It appears that the more heavily overprinted samples are often associated with the presence of anhydrite (e.g., pyrite-anhydrite-breccia, Zone 2) and also come from relatively deeper sections in the mound. There is also an indication of a trend toward increasing magnetic intensity with depth in the mound, coinciding with changes in lithology and suggesting that a stratigraphically distinct change in magnetic minerals may exist. Variations of the Koenigsberger ratio and the initial magnetic susceptibilities generally resemble those of NRMs. It is significant to note that this increase in NRM intensity also correlates precisely with a sharp increase in magnetic susceptibility. Both the NRM intensity and the magnetic susceptibility are parameters that likely reflect variations in type and amount of magnetic minerals within the mound. In this study, there is a high probability that both parameters reflect variations in the proportion of magnetic minerals as a result of pervasive hydrothermal activity that may have produced distinct zones wherein rocks have their own characteristic magnetic properties. The magnetic data thus have revealed information on the variation in the mineralogy, chemistry, and physical properties of the hydrothermal deposits and subsequent zone-refining processes.

A related problem to the above application is the magnetic identification and characterization of the magnetic minerals responsible for the observed magnetic properties. A knowledge of the primary magnetic mineralogy and subsequent mineralogic changes (and accompa- nying changes in magnetization) caused by secondary processes is critical for the understanding of the role of hydrothermal alteration. Results of measurements of low-temperature magnetic properties, unblocking and Curie temperatures, SEM observations, and Mössbauer effect spectrometry obtained from this study provide information for identifying magnetic carrier in Leg 158 cores. Although only a few of the shipboard thin sections revealed the existence of pyrrhotite (e.g., see p. 117 and p. 214 in Humphris, Herzig, Miller, et al., 1996), all the sulfide samples subjected to the low-temperature experiment showed the transition around $40 \mathrm{~K}$. Thus, the low-temperature magnetic phase transition is a sensitive indicator of pyrrhotite in the sulfide samples. It is quite possible that ferrimagnetic pyrrhotites contribute significantly to the remanent magnetization of the Leg 158 samples. We have no other direct way to test this hypothesis with our data at present other than to suspect that pyrrhotite may be responsible for the observed decrease in susceptibility of the two samples (Fig. 6) after they have been heated to $350^{\circ} \mathrm{C}$, as mentioned previously. A recent study by Menyeh and O'Reilly (1996) has reported a unblocking temperature $330^{\circ} \mathrm{C}$ for monoclinic pyrrhotite, which is in agreement with the observed unblocking temperature $\left(\sim 350^{\circ} \mathrm{C}\right)$ in this study. The combined investigation in this study suggests that the basalt samples from the TAG drilling areas contain magnetite as the main magnetic carrier and trace amounts of magnetite are also present in the sulfide samples. This is shown by the Verwey transition in the vicinity of $118 \mathrm{~K}$ during the low-temperature cycling, by the observed Curie temperatures $\left(500^{\circ}-540^{\circ} \mathrm{C}\right)$, and by the Mössbauer and SEM observations.

Distinctions between primary and secondary causes of magnetic property variations are also important because they reflect physical 


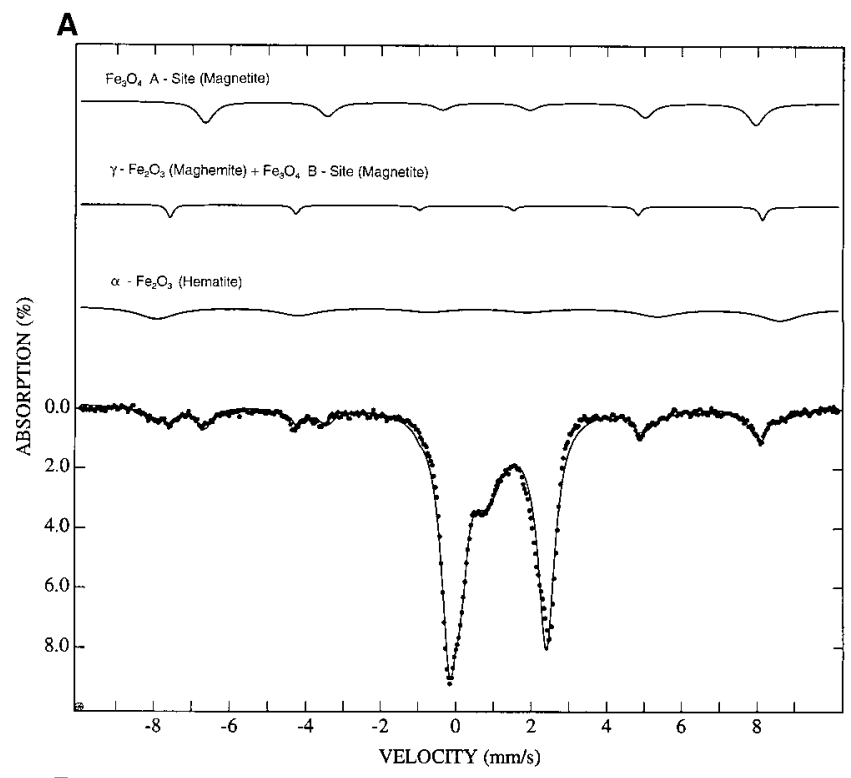

B

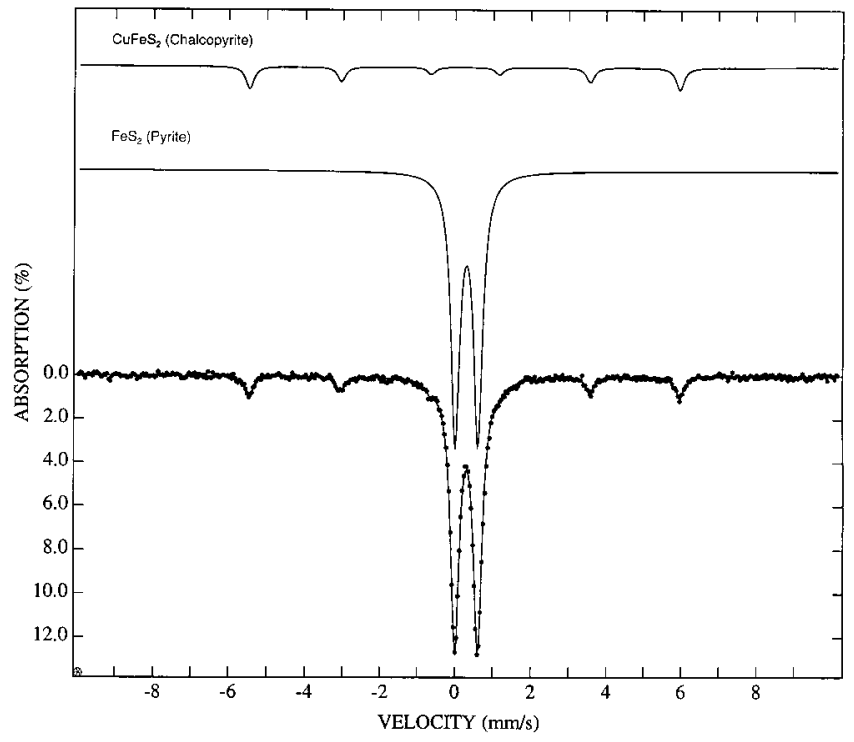

Figure 11. Mössbauer spectra of (A) Sample 158-957M-10R-1, 89-91 cm (basalt sample from the TAG-4 area) and (B) Sample 158-957O-4R-1, 30-32 $\mathrm{cm}$ (pyrite breccia from the TAG-5 area).

and chemical properties of hydrothermal fluids, as well as the timing of alteration in some settings. Preliminary shipboard observations clearly show that the complex sulfide stratigraphy in the TAG mound is a result of repeated episodes of brecciation, cementation, hydrothermal reworking, and replacement of preexisting sulfides. However, the relation among magnetic properties and the nature of the hydrothermal alteration regime at the TAG mound is not yet well understood. Rock magnetic data offer evidence to clarify some hypotheses and to explain some of the first-order features observed at the TAG mound. The very similar thermal demagnetization behavior of the pair sample from pyrite breccia and anhydrite vein (Fig. 6) could suggest that the samples were magnetized before development of the anhydrite vein and the magnetization was not subsequently modified by the veining activity, or that the magnetization was completely overprinted by the veining process. The stable inclination identified from both samples is close to the expected value at the drilling site and there is evidence in some of the breccias that secondary mineralization included some magnetic phases. Because of these observations (and lacking evidence to the contrary), we favor the speculation that the CRM of these samples involves resetting of the direction of remanence by veining activity, which could have occurred as recently as 60 yr. ago (Lalou et al., 1995). Future studies involving selective destructive demagnetization (Larson, 1981) would be helpful to confirm or disprove this speculation.

It is now well known that alteration of rocks under different mineralogical and geochemical conditions can change fundamental magnetic properties (e.g., Henshaw and Merrill, 1980; Goldhaber and Reynolds, 1991). In a number of geologic environments, the primary carriers of NRM have not only undergone changes in composition but changes in grain size since initial emplacement of the rock. For example, in sediments deposited on continental margins the original magnetite particles are reduced in grain size through chemical interaction with pore fluids (Ye and Halgedahl, 1994). In oceanic basalts, primary titanomagnetites not only become oxidized but often become smaller as a result of hydrothermal circulation (Johnson and Hall, 1978). Such changes in composition and grain size could cause major changes in domain structure and thus in the magnitude and direction of NRM (Ye and Halgedahl, 1994). Magnetic grain-size measurements in this study, as determined from hysteresis ratios $\left(H_{c} / H_{c}\right.$ and $\left.J_{r s} / J_{s}\right)$, SEM observation and the preliminary pARM acquisition data, show that the magnetic minerals of Leg 158 cores are of PSD size. This information together with the presence of pyrrhotite in the sulfide samples would suggest that substantial alteration has subsequently taken place and reset the original magnetization. The stable component (ChRM inclination values listed in Table 1) varies widely even on local scale, which alone may suggest that the remanence may be of a chemical origin. The original directions and magnitudes of magnetization may be changed by the authigenic growth of ferrimagnetic pyrrhotite $\left(\mathrm{Fe}_{7} \mathrm{~S}_{8}\right)$.

The demagnetization results of basalt samples shown in Figure 7 and listed in Table 1 revealed one of the most remarkable observations in this study. The mean inclination of the five basalt samples $\left(20.8^{\circ}\right)$ is significantly shallower than that which would be expected $\left(55^{\circ}\right)$ if the basaltic flows recorded the geomagnetic field when they were erupted. Although it is never certain whether these cores have been collected precisely vertically and deviations from the vertical of up to $5^{\circ}$ can easily go undetected, the shallow inclinations are so anomalous that we are obliged to consider carefully any hypotheses that might account for our results. These are of three general classes: tectonic (undetected tectonic dips or local rotations), geomagnetic (geomagnetic excursions) and rock magnetic (anisotropic remanence acquisition or chemical remagnetization).

\section{Undetected Tectonic Dips}

We must be aware of the existence of second-order tectonic movements that could affect the interpretation of the results obtained. For example, we are not sure whether the lavas were extruded horizontally or on a slope because of the volcanic cone from the which the lavas erupted. This problem clearly will affect the measured values of inclination. By their very nature, lava eruptions occur in a tectonically active environment. Successive eruptions inevitably cause disturbances to the previous basaltic lavas. In addition, Baag et al. (1995) have shown that in certain circumstances there can be deflection of paleomagnetic directions in the lava flow environment merely because of the magnetization of the underlying terrain. Although the hypothesis of undetected tectonic dips would account for the shallow inclinations naturally, it would be difficulty for this hypothesis to explain the rather larger variation in the inclinations over just a few centimeters along the same core section (see Table 1).

\section{Local Undetected Rotations}

More significant effects could arise from local undetected rotations. It has now been established that there are local rotations about a vertical axis (e.g., Kissel and Laj, 1989). Although vertical axis ro- 

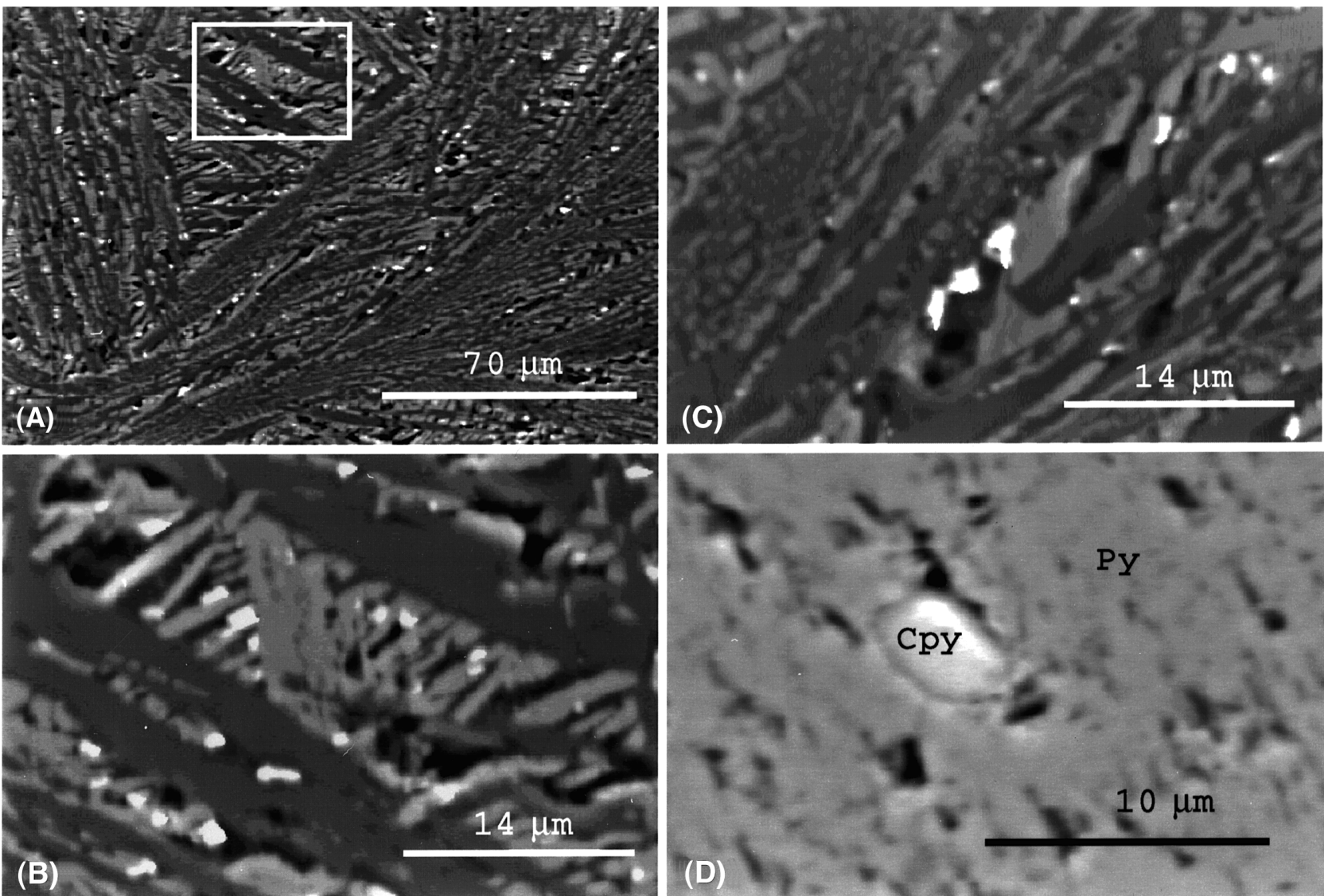

Figure 12. Representative SEM photomicrographs for Leg 158 cores. Conventions: dark gray = plagioclase; light gray $=$ clinopyroxene; bright spots $=$ titanomagnetite. A. Basalt sample (Sample 158-957M-10R-1, 89-91 cm) from the TAG-4 area, showing typical unaltered quenched texture of normal basalt. The scale bar is $70 \mu \mathrm{m}$. B. Image of a detailed region (upper-central) of (A). The scale bar is $14 \mu \mathrm{m}$. C. Another area of the same sample. The scale bar is $14 \mu \mathrm{m}$. D. Pyrite silica breccia sample (Sample 158-957C-16N-1, 17-19 cm) from the TAG-1 area, showing a chalcopyrite (Cpy) inclusion in a pyrite crystal (Py). The scale bar is $10 \mu \mathrm{m}$.

tations cause changes to occur in declination only, if such rotations cause are also accompanied by block faulting, then it is possible that changes in inclination can also occur (e.g., see McElhinny et al., 1996). Thus, one possible paleomagnetic interpretation of the shallow inclination result would be to propose that some tectonic rotation of the TAG mound has occurred since the basaltic lava flows were erupted. There is no geological evidence for such a rotation nor for faulting activity in the drilled site; it would require detailed seafloor mapping across a wide area in the region and much more careful work to confirm this interpretation.

\section{Geomagnetic Excursion}

Another possibility is that a geomagnetic excursion fortuitously occurred during the time when these basalts were being magnetized. Several recent studies have suggested that a number of geomagnetic excursions occurred during the last $50 \mathrm{k} . \mathrm{y}$., which is within the time when the TAG mound was formed. In a recent study of the absolute geomagnetic field intensity from 100 lava flows of core SOH-4 from the island of Hawaii, Garnier et al. (1996) observed shallower and, in some cases, negative inclinations between 16 and $38 \mathrm{ka}$. Similar inclination shallowing or even negative values were also observed from 19 ka lacustrine sediments from Black Rock Desert, Nevada (Ewing et al., 1994). Again in 1994, ultra-high resolution records ( $30 \mathrm{ka})$ from ODP Leg 155 drilled in the Amazon fan revealed a sharp increase in remanence intensity accompanied by a shift from very low to high inclinations (Cisowski et al., 1994). Viewed together, these studies yielded distinctive intervals of high $(>50 \mu \mathrm{T} ; 30-8 \mathrm{ka})$ and weak ( $<20 \mu \mathrm{T}$; 42-30 ka) paleointensities, which were assigned as the Lake Mungo and Laschamp excursions, respectively. Because of these characteristic paleointensity values, one can use these values as time markers for geomagnetic excursion studies. To examine the question whether these basalts recorded a local representation of a geomagnetic excursion that could be responsible for at least some of the anomalous inclinations, we must obtain reliable records of both paleointensity determination and radiometrical dating from the basalts, which remains for future investigations.

\section{Magnetic Anisotropy}

Preferred orientation of magnetic minerals and their easy axes of magnetization can deflect the directions of thermal remanent magnetization away from the ambient field (e.g., Stacey and Banerjee, 1974). To cause the large inclination deviations (more than $30^{\circ}$ ), however, this magnetic anisotropy would have to be exceptionally strong. On the contrary, the degree of anisotropy of two basalt samples that we measured on shipboard are very low (see p. 207 in Humphris, Herzig, Miller, et al., 1996), indicating that magnetic anisotropy is not a viable explanation.

\section{Chemical Remagnetization}

A less easily discounted hypothesis is that hydrothermal activity might have caused some kind of partial chemical remagnetization of the basalts. It is possible that there are sometimes certain circumstances present with rock samples which can prevent the acquisition 
of a CRM component parallel to the external field (Johnson and Hall, 1978). Recent study by Kent and Gee (1994) has shown that very young, essentially zero-age basalts from the seafloor spreading axis invariably show evidence of significant low-temperature oxidation of the remanence. The original thermal remanence may be lost very soon after emplacement of the oceanic basalts. In the case of the TAG-4 area, the presence of small amounts of maghemite and hematite as revealed by the Mössbauer spectrum obtained for a basalt sample would suggest that some magnetochemical remagnetization occurred that could cause the inclination deviation. However, in thin section under the petrographical microscope, the basalt sample appears to be quite fresh (Fig. 12). The plagioclase and pyroxene in the sample have not been altered and the titanomagnetite has euhedral crustal shape, indicating little alteration. Moreover, thermomagnetic curves in low field indicate single Curie temperature close to $550^{\circ} \mathrm{C}$ and are reversible. This is consistent with the impression typical of deuteric oxidation (that is, oxidation during original cooling) at high temperature. Clearly, the chemical remagnetization interpretation needs to be supported by more mineralogical observations and rock magnetic data to be convincing.

To sum up, we have failed to find a satisfying explanation for the shallow inclination results. Tectonic effects as discussed above, although not certain, are likely explanations. But they may not be the only cause. This discussion highlights the difficulty of studying the magnetization of young oceanic basalts. Much more additional work are needed to prove or disprove various possibilities and constrain the magnetic interpretation.

\section{CONCLUSIONS}

The following are the conclusions drawn from our comprehensive examination of the remanence magnetization and magnetic mineralogy of Leg 158 cores.

1. The combined investigation suggests that the magnetic properties of the basalt samples from the TAG-4 area are controlled mainly by magnetite and minor amounts of maghemite and hematite. Sulfide samples from the remaining TAG drilling areas contain a small amount of magnetite, pyrrhotite, and chalcopyrite. This study verifies that the low-temperature magnetic phase transitions are effective means of detecting the presence of pyrrhotite and trace magnetite in sulfides.

2. The magnetic minerals of the basalts are of variable particle size, but fall within the pseudo-single domain size range $(0.2-$ $14 \mu \mathrm{m})$.

3. Changes in magnetic properties correlate with variations in lithology, which results from abundance and sizes of magnetic minerals. The available evidence suggests that the remanence of sulfide samples is partly or wholly chemical in origin, probably as a result of heating and alteration related to hydrothermal fluid circulation. The magnetization was subsequently modified by veining activity.

4. A plausible scenario for the shallow inclination results obtained from basalt samples is that some tectonic rotation of the TAG mound has occurred since the basaltic lava flows were erupted.

5. It is clear from this study that a combination of paleomagnetic and rock magnetic studies on the same sulfide cores can provide important information that has considerable relevance to understanding the evolution of the hydrothermal mound. This study has demonstrated the potential value of paleomagnetic, rock magnetic, and petrological investigations in providing the essential link between magnetic property variations and the extent of mineral alteration.

\section{ACKNOWLEDGMENTS}

We thank Susan Humphris, Peter Herzig, and other shipboard scientists, the ODP marine technicians, Captain Ed Oonk, and crew of the JOIDES Resolution for their help during Leg 158. We also wish to express our appreciation to the shore-based ODP staff for all of their pre- and postcruise efforts. X.Z. wants to extend special thanks to Drs. Subir Banerjee, Bruce Moskowitz, and the paleomagnetism group of the Institute for Rock Magnetism at the University of Minnesota for the wonderful support and fruitful discussions. We gratefully acknowledge Drs. Laura Stokking, Gina Frost, and Jeff Gee for insightful reviews of this manuscript. Special thanks go to Jeff Gee who provided valuable criticisms and Rob Coe who provided useful advice and improved this paper. This research was supported by a grant to X.Z. from the U.S. Science Support Program of the Joint Oceanographic Institution, Inc. This paper is also Institute of Tectonic of UCSC contribution number 304 and publication number 9606 of the Institute for Rock Magnetism, which is funded by the W.M. Keck Foundation, The National Science Foundation, and the University of Minnesota.

\section{REFERENCES}

Baag, C., Helsley, C.E., Xu, S.-Z., and Lienert, B.R., 1995. Deflection of paleomagnetic directions due to magnetization of the underlying terrain. J. Geophys. Res., 100:10013-10027.

Banerjee, S.K., Hunt, C.P., and Liu, X.M., 1993. Separation of local signals from the regional paleomonsoon record of the Chinese Loess Plateau: a rock-magnetic approach. Geophys. Res. Lett., 20:843-846.

Campbell, A.C., Palmer, M.R., Klinkhammer, G.P., Bowers, T.S., Edmond, J.M., Lawrence, J.R., Casey, J.F., Thompson, G., Humphris, S., Rona, P.A., and Karson, J.A., 1988. Chemistry of hot springs on the Mid-Atlantic Ridge. Nature, 335:514-519.

Cisowski, S.M., Hall, F.R., and Ocean Drilling Program Leg 155 Scientific Party, 1994. Ultra-high resolution records of the Lake Mungo excursion and the Blake event from ODP Leg 155 cores drilled in the Amazon Fan. Eos, 75:190.

Cullity, B.D., 1972. Introduction to Magnetic Materials: Reading, MA (Addison-Wesley).

Day, R., Fuller, M., and Schmidt, V.A., 1977. Hysteresis properties of titanomagnetites: grain-size and compositional dependence. Phys. Earth Planet. Inter., 13:260-267.

Dekkers, M.J., 1988. Magnetic properties of natural pyrrhotite, Part I. Behavior of initial susceptibility and saturation-magnetization-related rock-magnetic parameters in a grain-size dependent framework. Phys. Earth Planet. Inter, 52:376-393.

Dekkers, M.J., Mattei, J.-L., Fillion, G., and Rochette, P., 1989. Grain-size dependence of the magnetic behavior of pyrrohotite during its low-temperature transition at $34 \mathrm{~K}$. Geophys. Res. Lett., 16:855-858.

Ewing, I., Negrini, R., and Nials, F., 1994. Possible record of 19 ka geomagnetic excursion in Pleistocene: Lacustrine sediments from the Delong Mammoth locality, Black Rock Desert, Nevada. Eos, 75:190.

Flanders, P.J., 1988. An alternating-gradient magnetometer. J. Appl. Phys., 63:3940-3945.

Garnier, F., Herrero-Bervera, E., Laj, C., Guillou, H., Kissel, C., and Thomas, D.M., 1996. Geomagnetic field intensity over the last 42000 years from Core SOH-4, Big Island, Hawaii. J. Geophys. Res., 101:585-600.

Goldhaber, M.B., and Reynolds, R.L., 1991. Relations among hydrocarbon reservoirs, epigenetic sulfidization, and rock magnetization: examples from the south Texas coastal plain. Geophysics, 56:748-757.

Hannington, M.D., Herzig, P.M., Tivey, M.K., Thompson, G., and Rona, P.A., 1992. Hydrothermal reworking of sulfide deposition in the TAG field, Mid-Atlantic ridge: evidence from the distribution of gold. Eos, 73:530-531.

Hannington, M.D., Thompson, G., Rona, P.A., and Scott, S.D., 1988. Gold and native copper in supergene sulfides from the Mid-Atlantic Ridge. Nature, 333:64-66.

Henshaw, R.C., Jr., and Merrill, R.T., 1980. Magnetic and chemical changes in marine sediments. Rev. Geophys. Space Phys., 18:483-504. 
Humphris, S.E., Herzig, P.M., Miller, D.J., et al., 1996. Proc. ODP, Init. Repts., 158: College Station, TX (Ocean Drilling Program).

Humphris, S.E., Herzig, P.M., Miller, D.J., Alt, J.C., Becker, K., Brown, D., Brügmann, G., Chiba, H., Fouquet, Y., Gemmell, J.B., Guerin, G., Hannington, M.D., Holm, N.G., Honnorez, J.J., Itturino, G.J., Knott, R., Ludwig, R., Nakamura, K., Petersen, S., Reysenbach, A.-L., Rona, P.A., Smith, S., Sturz, A.A., Tivey, M.K., and Zhao, X., 1995. The internal structure of an active sea-floor massive sulphide deposit. Nature, $377: 713-716$

Humphris, S.E., Kleinrock, M.C., and the Deep-TAG Team, 1994. Detailed morphology and the distribution of venting at the active TAG hydrothermal mound, $26^{\circ} \mathrm{N}$, Mid-Atlantic Ridge. Eos, 75:660.

Humphris, S.E., and Thompson, G., 1978. Hydrothermal alteration of oceanic basalts by seawater. Geochim. Cosmochim. Acta, 42:107-125.

Johnson, H.P., and Hall, J.M., 1978. A detailed rock magnetic and opaque mineralogy study of the basalts from the Nazca Plate. Geophys. J. R. Astron. Soc., 52:45-64.

Johnson, H.P., and Pariso, J.E., 1993. Variations in oceanic crustal magnetization: systematic changes in the last 160 million years. J. Geophys. Res., 98:435-445.

Kent, D., and Gee, J., 1994. Do oceanic basalts preserve a record of paleointensity variations? Eos, 75:192

Kirschvink, J.L., 1980. The least-squares line and plane and the analysis of palaeomagnetic data. Geophys. J. R. Astron. Soc., 62:699-718.

Kissel, K., and Laj, C. (Eds), 1989. Paleomagnetic Rotations and Continental Deformation: Norwell, MA (Kluwer Acad.).

Lalou, C., Reyss, J.-L., Brichet, E., Rona, P.A., and Thompson, G., 1995. Hydrothermal activity on a $10^{5}$-year scale at a slow-spreading ridge, TAG hydrothermal field, Mid-Atlantic Ridge $26^{\circ}$ N. J. Geophys. Res., 100:17855-17862.

Larson, E.E., 1981. Selective destructive demagnetization, another microanalytic technique in rock magnetism. Geology, 9:350-355.

McElhinny, M.W., McFadden, P.L., and Merrill, R.T., 1996. The time-averaged paleomagnetic field 0-5 Ma. J. Geophys. Res., 101:25007-25027.

Menyeh, A., and O'Reilly, W., 1996. Thermoremanent magnetization in monodomain monoclinic pyrrhotite $\mathrm{Fe}_{7} \mathrm{~S}_{8}$. J. Geophys. Res., 101:2504525051.

O'Reilly, W., 1984. Rock and Mineral Magnetism: New York (Chapman and Hall).

Rochette, P., Fillion, G., Mattéi, J.-L., and Dekkers, M.J., 1990. Magnetic transition at 30-34 Kelvin in pyrrhotite: insight into a widespread occurrence of this mineral in rocks. Earth Planet. Sci. Lett., 98:319-328.

Rona, P.A., Klinkhammer, G., Nelson, T.A., Trefry, J.H., and Elderfield, H., 1986. Black smokers, massive sulfides and vent biota on the Mid-Atlantic Ridge. Nature, 321:33-37.

Rona, P.A., and Thompson, G., 1993. Introduction to Atlantic hydrothermal activity. J. Geophys. Res., 98:9621-9623.
Schwarz, E.J., 1965. Thermomagnetic properties of sulfide ore from the Noranda area, Canada, measured with a magnetic balance. Can. J. Phys., 43:220-226.

Stacey, F.D., and Banerjee, S.K., 1974. The Physical Principles of Rock Magnetism: New York (Elsevier), Dev. Solid Earth Geophys., 5.

Stein, C.A., and Stein, S., 1994. Constraints on hydrothermal heat flux through the oceanic lithosphere from global heat flow. J. Geophys. Res., 99:3081-3095.

Thompson, G., Humphris, S.E., Schroeder, B., Sulanowska, M., and Rona, P.A., 1988. Active vents and massive sulfides at $26^{\circ} \mathrm{N}$ (TAG) and $23^{\circ} \mathrm{N}$ (Snakepit) on the Mid-Atlantic Ridge. Can. Mineral., 26:697-711.

Tivey, M.A., Rona, P.A., and Schouten, H., 1993. Reduced crustal magnetization beneath the active sulfide mound, TAG hydrothermal field, MidAtlantic Ridge $26^{\circ}$ N. Earth Planet. Sci. Lett., 115:101-115.

Tivey, M.K., Humphris, S.E., Thompson, G., Hannington, M.D., and Rona, P.A., 1995. Deducing patterns of fluid flow and mixing within the TAG active hydrothermal mound using mineralogical and geochemical data. $J$. Geophys. Res., 100:12527-12555.

Van Dover, C.L., Fry, B., Grassle, J.F., Humphris, S.E., and Rona, P.A., 1988. Feeding biology of the shrimp Rimicaris exoculata at hydrothermal vents on the Mid-Atlantic Ridge. Mar. Biol., 98:209-216.

Verwey, E.J., Haayman, P.W., and Romeijn, F.C., 1947. Physical properties and cation arrangements of oxides with spinal structure. J. Chem. Phys., 15:181-187.

Wirsen, C.O., Jannasch, H.W., and Molyneaux, S.J., 1993. Chemosynthetic microbial activity at Mid-Atlantic Ridge hydrothermal vent sites. J. Geophys. Res., 98:9693-9703.

Wooldridge, A.L., Harrison, C.G.A., Tivey, M.A., Rona, P.A., and Schouten, H., 1992. Magnetic modeling near selected areas of hydrothermal activity on the Mid-Atlantic and Gorda ridges. J. Geophys. Res., 97:1091110926.

Ye, J., and Halgedahl, S.L., 1994. Bitter patterns observed on pyrrhotite particles during the mechanical reduction of grain size. Eos, 75:189.

Zhao, X., Roperch, P., and Stokking, L.B., 1994. Magnetostratigraphy of the North Aoba Basin. In Greene, H.G., Collot, J.-Y., Stokking, L.B., et al., Proc. ODP, Sci. Results, 134: College Station, TX (Ocean Drilling Program), 457-474.

Zijderveld, J.D.A., 1967. AC demagnetization of rocks: analysis of results. In Collinson, D.W., Creer, K.M., and Runcorn, S.K. (Eds.), Methods in Palaeomagnetism: New York (Elsevier), 254-286.

Date of initial receipt: 3 June 1996

Date of acceptance: 31 January 1997 Ms 158SR-228 